\section{Child Labor}

Cause, Consequence, and Cure, with Remarks on International Labor Standards

Kaushik Basu
Should child labor be banned outright? Should the World Trade Organization be given the responsibility to discourage child labor using trade sanctions? The answer to this complicated problem depends on the economic milieu, says Basu.

The World Bank

Office of the Senior Vice President Development Economics

December 1998 


\section{Summary findings}

At least 120 million of the world's children aged 5 to 14 worked full-time in 1995, most of them under hazardous, unhygienic conditions, for more than 10 hours a day. This is an old problem worldwide but particularly so in Third World countries in recent decades. What has changed, with globalization, is our awareness of these child laborers. (The International Labour Organisation distinguishes between "child work," which could include light household chores and could have some learning value, and "child labor," a pejorative phrase.)

By bringing together the main theoretical ideas, Basu hopes to encourage both more theoretical research and empirical work with a better theoretical foundation.

Among other things, Basu observes that:

- The problem is most serious in Africa, where the child-labor participation rate is 26.2 percent. The rate is 12.8 percent in Asia. But since 1950, the trend is a decline in that participation rate worldwide. For most Latin American countries, the decline is notable but less marked than in Asia. In large parts of Africa, including Ethiopia, the problem has been extremely persistent, but even there the trend is downward.
- Child labor has not always been considered evil, and there is no consensus on why it began to decline. In some (not all) countries legislative acts declared it illegal, in some there were rules about compulsory education, and increasing prosperity generally made families less likely to experience poverty if their children weren't working.

- Mandating compulsory education is regarded as more effective than outlawing child labor, because attendance at school is easier to monitor, but some experts believe economic progress is the answer to the problem. The justification for many interventions is that the state is more concerned about the well-being of children than their parents are; Basu believes such an assumption to be wrong when child labor occurs as a mass phenomenon rather than as isolated abuse.

Basu argues that, in some economies, the market for labor may exhibit multiple equilibria, with one equilibrium having low adult wage and a high incidence of child labor and another equilibrium exhibiting high adult wage and no child labor.

The model is used to provide a framework for analyzing the role of international labor standards.

This paper - a product of the Office of the Senior Vice President, Development Economics - is part of a larger effort in the Bank to promote understanding of the causes of child labor. The study was funded by the Bank's Research Support Budget under the research project "Literacy and Child Labor" (RPO 683-07). Copies of this paper are available free from the World Bank, 1818 H Street NW, Washington, DC 20433. Please contact Michelle Mason, room MC4-338, telephone 202-473-0809, fax 202-522-1158, Internet address mmason1@worldbank.org. The author may be contacted at kbasu@worldbank.org. December 1998. (73 pages)

The Policy Research Working Paper Series disseminates the findings of work in progress to encourage the exchange of ideas about development issues. An objective of the series is to get the findings out quickly, even if the presentations are less than fully polished. The papers carry the names of the authors and should be cited accordingly. The findings, interpretations, and conclusions expressed in this paper are entirely those of the authors. They do not necessarily represent the view of the World Bank, its Executive Directors, or the countries they represent. 


\title{
CHILD LABOR: \\ Cause, Consequence and Cure, with Remarks on International Labor \\ Standards
}

\author{
KAUSHIK BASU \\ Department of Economics \\ Uris Hall \\ Cornell University \\ Ithaca, NY 14850 \\ Fax 607-255-2818 \\ Email kb40@cornell.edu \\ and \\ Office of the Senior Vice President, Development Economics \\ World Bank \\ 1818 H Street, N.W. \\ Washington, DC 20433 \\ Fax 2025221157
}

Key words: child labor, international labor standards, labor law, harassment, unemployment

JEL Classification: J13, I31, D10

Acknowledgments: For useful comments and suggestions I am grateful to Jens Andvig, Kebebew Ashagrie, Alaka Basu, Clive Bell, Francois Bourguignon, George Boyer, Dan Bromley, Jean Dreze, Patrick Emerson, Gary Fields, Garance Genicot, Noemi Giszpenc, Subbiah Kannapan, Ayal Kimhi, Elizabeth King, Luis-Felipe Lopez-Calva, Dani Rodrik, Pham Hoang Van, Henry Wan and to three anonymous referees of the journal. I have also benefited from seminar presentations at the Indian Statistical Institute in New Delhi, the Stockholm School of Economics, the Indira Gandhi Institute of Development Research, the University of Wisconsin, Notre Dame University, the World Bank, and the NEUDC Conference at Yale University. 


\section{CONTENTS}

1. Introduction

2. The Empirical Context

A Contemporary

B. Historical

3. The Policy Questions

4. Early Theoretical Ideas

5. Bargaining Models

A. Intra-household Bargaining

B. Extra-household Bargaining

6. Multiple Equilibria and Government Intervention

A. Model with Altruism

B. Norms

C. Distribution and Unemployment

D. Dynamics

7. Sexual Harassment and Child Labor

8. International Labor Standards

9. Conclusion 


\section{CHILD LABOR:}

\section{Cause, Consequence and Cure, with Remarks on International Labor Standards}

\section{Introduction}

According to the Bureau of Statistics of the International Labor Organization, in 1995, at least 120 million of the world's children between the ages of 5 and 14 years did full-time, paid work (ILO, 1996; Ashagrie, 1998). Many of them worked under hazardous and unhygienic conditions and for more than 10 hours a day. This is not a new problem. In different parts of the world, at different stages of history, the laboring child has been a part of economic life. In particular, children have worked in large numbers in factories from the time of the industrial revolution in Europe and from the mid-nineteenth century in America. In contemporary times, the incidence of child labor is very high in Third World countries, and it has been that way for several decades now.

What has increased is the awareness of and concern for children who work as laborers. This is caused, in part, by the increasing globalization of the world, which has brought not only more information about the condition of labor in different nations to academics and activists the world over, but also goods produced by children in far away lands into the hands of consumers in high-income countries. This has, in turn, brought two very different kinds of people on the same platform -- individuals who are genuinely concerned about the plight of children in poor countries and those who comprise the forces of protectionism in developed countries. The two have rallied together to support a variety of interventions in Third-World labor markets, ranging from banning imports into industrialized nations of products 'tainted' by child labor inputs, through setting international labor standards to be monitored by international organizations such as the WTO or 
ILO, to labeling products which used child labor so as to give the consumer the option to boycott them.

Any such intervention is likely to have not just an impact on the well-being of children, but also spillover effects on others. It is imperative, therefore, that policy in this area be based on careful analysis and research, and not just emotion or impulse.

The literature on child labor is enormous but it is scattered across the social sciences and piecemeal, lacking a common theoretical foundation. The aim of this paper is to provide an analytical survey of this field, keeping in mind that this is an area where the primary reason for theorizing is to, ultimately, influence policy. The main policy debates and options are summarized in Section 3. Section 2 provides the factual background of the problem, drawing on large-scale data sets and on the substantial literature rooted in formal and informal micro studies. Thanks to the enormity of the problem in the last century, there is also a sizeable historical literature on the subject. ${ }^{1}$ I draw on this, not comprehensively, but keeping in mind contemporary concerns and the analytical focus of this paper and report this in Section 2B.

Sections 4 through 7 are on models and theories related to child labor. The traditional argument for government intervention in child labor markets is based on the standard claim of externalities. Such arguments are recapitulated in Section 4, which also summarizes the early theoretical ideas of some classical economists. Conventional models treat the household as a single decision-making unit (Becker, 1964); but once we recognize that there may be divergence of interests within the household there is scope for arguing that children are victimized. There is

${ }^{1}$ See, for instance, Anderson (1971), Goldin (1979), Vincent (1981), Cunningham (1990), Nardinelli (1990), Moehling (1995), Horrell and Humphries (1995, 1995a), Cunningham and Viazzo (1996), and Galbi (1997). 
now a whole range of bargaining models available for analyzing intra-household decision making, some of which explicitly look into the question of child labor (for example, Moehling, 1995, and Gupta, 1998). These models are summarized in Section 5, along with some suggestions for extensions. If there are no externalities and no divergence of interest in the household, can there still be a case for intervention? Section 6 sketches a model (Basu and Van, 1998) which shows that, for a class of situations, the answer is yes, because of the labor market's propensity to have multiple equilibria. The model of Section 7 sketches an argument against harassment and shows how this kind of analysis can be used in thinking about child-labor legislation.

Child labor regulation is an important part of the current debate on international labor standards; and Section 8 discusses some questions concerning international labor standards in which the problem of child labor arises explicitly. Section 9 consists of brief concluding remarks.

\section{The Empirical Context}

To place this analytical survey in context and also to keep our focus on real-world policy concerns, it is useful to begin by briefly recounting the world's actual experience with child labor. This exercise is broken up into two subsections, one which describes contemporary macro aggregates, and another which describes the historical roots of the problem.

\section{A. Contemporary}

Any estimate of child labor depends on how we define "child" and "labor" and on the quality of statistics available. The ILO Convention No. 138 specifies 15 years as the age above 
which, in normal circumstances, a person may participate in economic activity. ${ }^{2}$ Following this, most studies treat a person of age less than 15 years as a "child". As a study by the US Department of Labor notes, while ILO's Convention 138 'has been ratified by only about one quarter of the ILO membership, it has nevertheless been internationally recognized and used as a blue print for national policy and practice with respect to child labor" (United States Department of Labor, 1993, p.5). This observation carries even greater weight because the US itself is not a signatory to the convention.

A child is classified as a "laborer" if the child is "economically active" (Ashagrie, 1993). ${ }^{3}$ Governments and international organizations usually treat a person as economically active or "gainfully employed" if the person does work on a regular basis for which he or she is remunerated or which results in output destined for the market. The Indian census, for instance, explicitly uses such a convention. We know from micro studies that if we instead include those 'invisible' workers who do unpaid work, which finds no market outlet, such as work within the household, the estimates of child labor can shoot up. Jayaraj and Subramanian's (1997) recent calculations for the state of Tamilnadu, India, show that for the 5-14 age group in 1983, if they use the restrictive definition of the kind that the ILO uses, $13 \%$ of all children were laborers.

${ }^{2}$ While this is so under "normal circumstances", Convention No. 138 does specify some special cases. Thus for "light work" the age limit is 13 years and for "hazardous work" it is 18 years (ILO, 1996). See UNICEF (1994) for a discussion of Convention No. 138 and for alternative conceptions of what constitutes child labor (see also Knutsson, 1997).

${ }^{3}$ The ILO often distinguishes between "child work" and "child labor", the latter being used to describe the more pejorative part of "child work", whereas "child work" in itself could including doing light household chores and can actually have some learning value (ILO, 1995, p. 1). I shall, however, here use "work" and "labor" interchangeably, while referring to what the ILO calls "child labor". 
Using the more liberal definition the figure jumps to $33 \%{ }^{4}$

Even after the definitions are sorted out (to the extent that they can be) official data on child labor tends to be deficient because of the likelihood of under-reporting. In most countries there are laws which place restrictions on child labor, ranging from an outright ban (as in most industrialized countries) to other kinds of limitations such as an outright ban on child labor for very small children, and for all children in hazardous industries (as, for instance, in Bangladesh, India and Pakistan). Thus it is natural for guardians and employers to hide the information of 'illegal' work by children.

Keeping all these caveats in mind, and cobbling information from various sources, Kebebew Ashagrie (1993) (see also Grootaert and Kanbur, 1995) was the first to put together an international data set on child labor. He found that in 1990 there were nearly 79 million children who were economically active. Most of them (57 million) were in Asia. However, over the previous 10 years, he found that the absolute number of children working was declining in Asia but rising in the Americas and Africa, sharply in the latter. This data is summarized in Table 1.

It is worth pointing out that while Ashagrie's (1993) estimates, as summarised in Table 1, have the virtue of comprehensiveness, they generally give lower values for the incidence of child labor than other existing estimates. Indeed, more recent work by Ashagrie (1998) and the ILO (1996), which were based on detailed experimental surveys in Ghana, India, Indonesia and

${ }^{4}$ This point is reinforced at the all-India level by Weiner $(1996$, p. 3007) who argues that "most of the 90 million children not in school are working children". See also Labenne (1995) for alternative definitions of child labor and how different variables affect them in India. Some economists adopt the convention of distinguishing between "work" and "home care", classifying children who do not attend school and are not formally employed as "home care laborers" (Cartwright and Patrinos, 1998). 
Senegal, have resulted in upward revisions of these figures. In addition, it must be kept in mind that all figures quoted in this section relate to full-time work. Recent ILO estimates suggest that if "child labor" is taken to include those who do part-time work, the numbers more than double.

Thus the 1995 figure, quoted at the start of this essay, for child labor would rise to 250 million.

Table 1. Child Labor: Aggregate and Distribution

\begin{tabular}{|c|c|c|c|}
\hline & \multicolumn{3}{|c|}{ Number of Children (below 15 years) Working (in thousands) } \\
\hline & $\mathbf{1 9 8 0}$ & $\mathbf{1 9 8 5}$ & $\mathbf{1 9 9 0}$ \\
\hline World & 87,867 & 80,611 & 78,516 \\
\hline Africa & 14,950 & 14,536 & 16,763 \\
\hline Americas & 4,122 & 4,536 & 4,723 \\
\hline Asia & 68,324 & 61,210 & 56,784 \\
\hline East Asia & 39,725 & 33,463 & 22,448 \\
\hline Southeast Asia & 6,518 & 6,079 & 5,587 \\
\hline South Asia & 20,192 & 19.834 & 27,639 \\
\hline
\end{tabular}

Source: Ashagrie (1993)

The Asian figures are very large; but it has to be kept in mind that Asia's population is very large. So to get a better idea of the magnitude of the problem, we may wish to look at the 'participation rate', that is, the percentage of children of the relevant age group who work as laborers. In terms of participation rates, for the $10-14$ years category, the problem in 1990 was most serious in Africa, with a figure of $27.87 \%$. The participation rate for Asia was $15.19 \%$. 
These statistics are available from the ILO (1996a), which has now compiled inter-country data on child labor from 1950 to 1995 , along with projections, up to 2010. A summary of this information is provided in Table 2 and Graph 1. The first five rows show the distribution of child labor across the main continental regions of the world. In addition, a sample of five nations, from among those which had a participation rate of over $20 \%$ in 1950 , are represented in the table to give the reader a glimpse of how varied the experience of different nations has been.

Table 2. Participation Rates for Children, 10 - 14 Years

\begin{tabular}{|c|l|l|l|l|l|l|l|l|}
\hline & $\mathbf{1 9 5 0}$ & $\mathbf{1 9 6 0}$ & $\mathbf{1 9 7 0}$ & $\mathbf{1 9 8 0}$ & $\mathbf{1 9 9 0}$ & $\mathbf{1 9 9 5}$ & $\mathbf{2 0 0 0}$ & $\mathbf{2 0 1 0}$ \\
\hline World & 27.57 & 24.81 & 22.30 & 19.91 & 14.65 & 13.02 & 11.32 & 8.44 \\
\hline Africa & 38.42 & 35.88 & 33.05 & 30.97 & 27.87 & 26.23 & 24.92 & 22.52 \\
\hline Latin America \& Caribbean & 19.36 & 16.53 & 14.60 & 12.64 & 11.23 & 9.77 & 8.21 & 5.47 \\
\hline Asia & 36.06 & 32.26 & 28.35 & 23.42 & 15.19 & 12.77 & 10.18 & 5.60 \\
\hline Europe & 6.49 & 3.52 & 1.62 & 0.42 & 0.10 & 0.06 & 0.04 & 0.02 \\
\hline Ethiopia & 52.95 & 50.75 & 48.51 & 46.32 & 43.47 & 42.30 & 41.10 & 38.79 \\
\hline Brazil & 23.53 & 22.19 & 20.33 & 19.02 & 17.78 & 16.09 & 14.39 & 10.94 \\
\hline China & 47.85 & 43.17 & 39.03 & 30.48 & 15.24 & 11.55 & 7.86 & 0.00 \\
\hline India & 35.43 & 30.07 & 25.46 & 21.44 & 16.68 & 14.37 & 12.07 & 7.46 \\
\hline Italy & 29.11 & 10.91 & 4.12 & 1.55 & 0.43 & 0.38 & 0.33 & 0.27 \\
\hline
\end{tabular}

Source: ILO (1996a) 


\section{Graph 1. Trends in the Participation Rates}

\section{Percent of Economically Active Children Bet ween 10-14 Years of Age.}

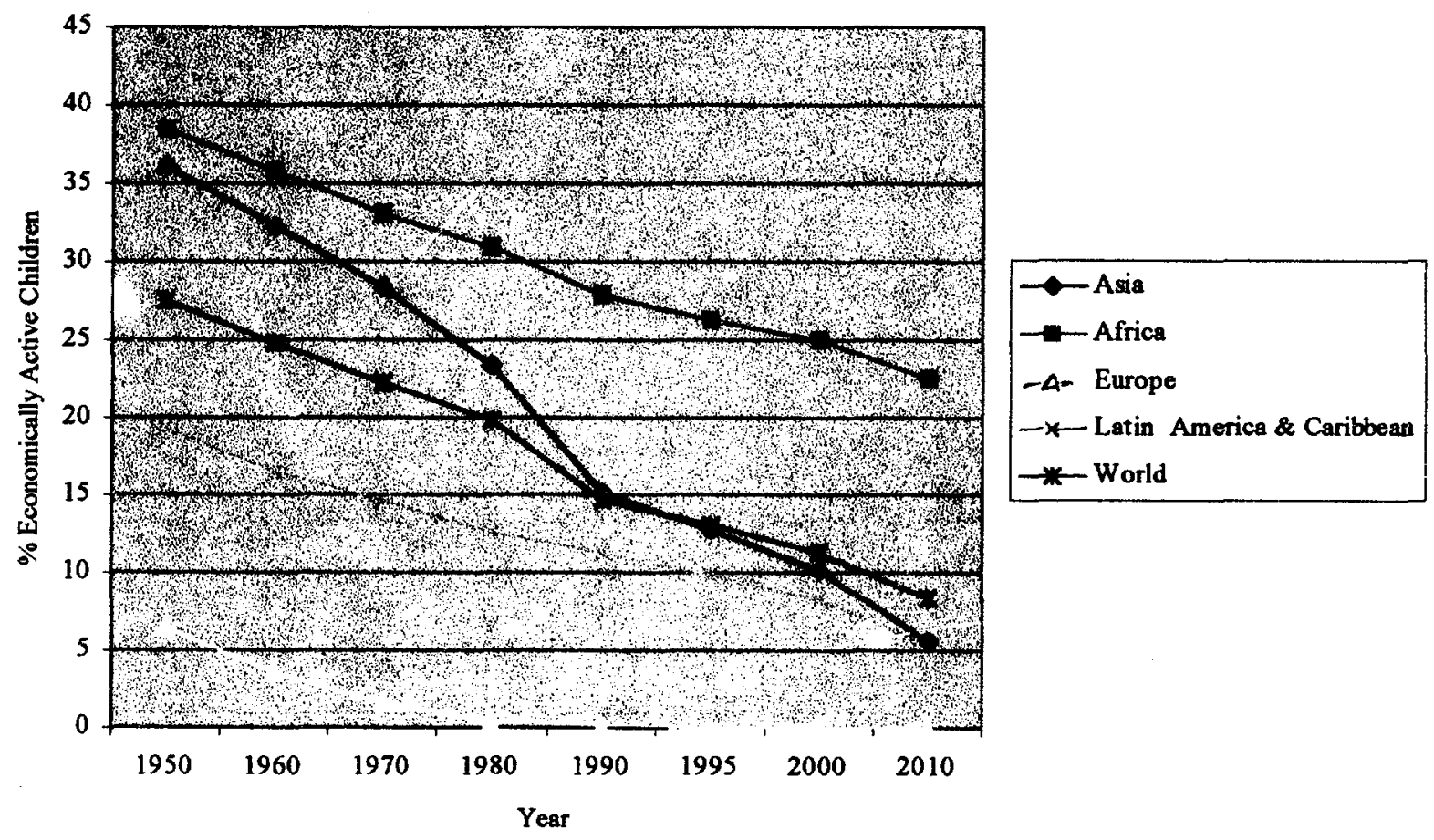


As this graph and table show, the problem is enormous but the trend, fortunately, is in the right direction. For some countries, such as China, India, and especially Italy, the decline in the participation rate of children has been quite rapid. For most Latin American nations, such as Brazil, the decline is notable but less marked. The problem has been extremely persistent in large parts of sub-Saharan Africa, as illustrated by Ethiopia; but even here the trend is downwards. For China, interestingly, the decline is most rapid between 1980 and 1990 , which happens to coincide with the period of very rapid growth in incomes."

The overall growth of an economy is by no means the only factor, nor for that matter the most important factor, in the mitigation of child labor. Changes in technology, improvement in the conditions of the adult labor market, and the availability of decent schooling can all lead to children being voluntarily withdrawn from the labor force. Levy (1985), in a study of rural Egypt, found that mechanization did contribute to a diminution in child labor and also fertility. The cultivation of cotton, specially weeding and picking, has conventionally been child-labor intensive in Egypt. So changes in cropping pattern, away trom cotton, played a role in curbing child labor. We shall return to the subject of how to curb child labor later. Let us, before that, take a look at the historical backdrop of the contemporary situation, just described.

${ }^{5}$ One has to be careful not to read too much into these macro statistics. Most of the data are constructed by extrapolating from a few small-scale detailed studies. Even in the US, where a considerable amount of money and effort goes into collecting labor data, the amount of child labor is prone to be under-reported (Kruse and Mahoney, 1998). The problem must be that much more acute for developing countries, especially ones where state control makes it difficult for independent researchers to collect and verify data. 


\section{B. Historical}

Here is an excerpt from an interview of a child laborer.

Q. "What were your hours of labor, do you recollect. in that mill?"

A. $\quad$ "In the summer season we were very scarce of water."

Q. $\quad$ "But when you had sufficient water, how long did you work?"

A. "We began at 4 o'clock in the morning and worked till 10 or 11 at night; as long as we could stand upon our feet."

Q. "You hardly could keep up for that length of time?"

A. $\quad$ "No, we often fell asleep."

This could have been a contemporary interview, but it is not: it took place on 23 June

1832. The interview was conducted by a British Parliamentary committee, investigating the conditions of child labor in the United Kingdom. In this case the interviewee was Peter Smart. who had worked as a laborer from the age of 5 years. Peter Smart was not an exception. The Select Committee Report of 1831-32 from which I have taken the above interrogation (see p. 338, British Parliamentary Papers, 1968), is an enormous document, reporting on a series of interviews of both child laborers and factory-owners and managers. The story that emerges has little variation. The children worked long hours, were frequently beaten and were paid a pittance

British census data reveal that the incidence of child labor was very high in the early and middle nineteenth century. According to the Census of England and Wales in $1801,30.9^{\circ} \mathrm{o}$ of boys in the 10-14 age-group were laborers and the statistic for girls was $20.5^{\circ} \% . "$ A comparison with Table 2 shows that though the incidence of child labor was higher for Africa and Asia in 1950 , currently no continental region in the world has higher participation rates than Britain did in the middle of the last century. However, some nations, such as Ethiopia, have a much higher rate

'Going by the census, child labor in England and Wales peaked in 1861 for boys, and in 1871 for girls. The participation rates dropped off rapidly after 1871 (see Cunningham, 1996). 
(see Table 2). While the participation of children in the labor force may have been particularly high in Britain, the experience of other industrializing nations, such as Belgium, the U.S. and Japan were not very different (De Herdt, 1996; Parsons and Goldin, 1989; and Saito. 1996). ${ }^{\text {? }}$ While, historically, attention was drawn to the child labor problem during the industrial revolution, there are scholars who have argued that the problem was not especially acute during this time. According to them, child labor was comparably widespread even in the early eighteenth century, though the children did not work in factories at that time. But most of such observations are based on impressions rather than statistics. Moreover, the experience of working in farms, alongside ones parents, is arguably less grim than working in factories for 14 hours at a stretch (Cunningham, 1990), as suggested by the interview quoted above.

This view finds reinforcement in a contemporary study conducted by researchers at the Delhi School of Economics ${ }^{8}$ and the Indian Social Institute which shows that child labor in rural areas is often 'light', so much so that these children ought to be able to get education without seriously cutting into their work commitments, if they had access to proper schools (Bhatty et al, 1997). This study, based on interviewing 1, 221 rural Indian parents, found that among the outof-school children, about half worked less than 3 hours on the day preceding the survey and only $18 \%$ worked more than eight hours. The story is very different for factory workers and organized child labor, as, for instance, in the match-industry of Sivakasi (Kothari, 1983; Kulkarni, 1983).

The large incidence of child labor in the industrialized nations in the last century, gave rise

${ }^{7}$ For a general discussion of inter-country experience in the last century see Weiner (1991) and Cunningham and Viazzo (1996). this.

${ }^{8}$ I am grateful to Jean Dreze, who was part of this team, for a very valuable discussion on 
to a lot of debate and ideas from which we can benefit today. ${ }^{9}$ What is quite striking and noteworthy is that child labor has not always been thought of as an evil. There have been times when it was treated as unpleasant to the child, but nevertheless desirable, somewhat akin to our contemporary view of education. Thus we find an eighteenth-century writer observing that "parents, whose childhood was spent in idleness, have contracted every absurd prejudice against the employment of children, as unnatural, cruel and unprofitable". ${ }^{10}$ B. L. Hutchins and A. Harrison (1903) have recounted many instances of this attitude. They quote, for instance, a 1770 document, which argues that "being constantly employed at least twelve hours in a day ... we hope the rising generation will be so habituated to constant employment, that it would at length prove agreeable and entertaining to them ... [From] children thus trained up to constant labor we may venture to hope the lowering of its price" (Hutchins and Harrison, 1903, p.5) 11

Nevertheless, as the excesses of child labor increased through the early nineteenth century, opposition also mounted. And by the late nineteenth century child labor was on the decline. It is true that this institution would soon be 'exported' out of the industrialized nations, as the practice of child labor got shifted to the colonies, but within the boundaries of industrialized nations, it was undeniably on the way out.

${ }^{9}$ For a lucid summary account, see Cunningham and Viazzo (1996a).

${ }^{10}$ Quoted in Cunningham (1990, p. 120).

${ }^{11} B y$ the time the child labor debate picked up steam in the United States in the late nineteenth century, child labor was viewed as it is done today, as an unmitigated evil. The reasons given against the institution of child labor are also rather like the ones given today, the important exception being the argument of "race degeneracy". Child labor, it was reasoned, should be ended in the South because that would help "the preservation of its Anglo-Saxon stock" (Kelway, 1906, p.261). Similar sentiment was expressed repeatedly, by several authors, in the March 1906 issue of The Annals of the American Academy of Political and Social Science. 
How did this happen? There is no consensus on this. On the one hand there were a series of legislative acts limiting child labor and ultimately declaring it unconditionally illegal, and there were also rules about compulsory education which made it difficult for children to work full time. On the other hand, the increasing prosperity of Europe, the USA and Japan made it easier for parents to pull children out of work without having to fear that this would commit the household to poverty.

All these factors must have played a role with important regional and sectoral differences. Scholliers' (1995, p. 208) study of child labor in Ghent, Belgium, revealed that, by the midnineteenth century "the number of children under twelve had diminished substantially, and this without any legislative intervention". By contrast, the law played an important role in the declineof child labor in the cotton mills of Manchester (Bolin-Hort, 1989). Brown, Christiansen and Philips (1992) in their study of the fruit and vegetable canning industry in the U.S., between 1880 and 1920, found that the decline in the incidence of child labor was due to both natural economic reasons and legal factors, though the economic forces were the stronger explanatory variable.

There is, however, some agreement on one matter. If one is using legislative fiat to fight child labor, it is more effective to legislate for compulsory education instead of simply banning child labor (Weiner, 1991). One good reason for this is that a child's presence in school is easier to monitor (and thus ensure) than a child's absence from work.

There were others who in the context of the historical debate felt that legislation, whether it be for compulsory education or a direct ban on child labor, cannot be as effective as economic progress; and that the right policy is to wait for economic progress. Such a position is associated with Nardinelli (Nardinelli, 1990; and, for discussion, see Cunningham and Viazzo, 1996). 
One of the more systematic investigations of the historical role of law in the decline of child labor occurs in the work of Carolyn Moehling (1998). Her focus of study is the United States from 1880 to 1910 . This is part of the period during which the incidence of child labor dropped off rapidly. It was also a period of activism against child labor. In 1900 twelve states had a minimum age limit of 14 years for manufacturing employment. By 1910 thirty-two states had such a restriction. The question that she investigates is whether it was the legislation that caused the decline in child labor or whether it was the diminishing dependence of industry on child labor that made the judicial activism possible.

The method that she uses is the "difference of difference of difference" (DDD). A more standard method (for instance, one used by Angrist and Krueger, 1991, and Margo and Finegan; 1996) would have required her to compare the difference in the difference in the occupation rates of children aged 13 years and 14 years in states which have a law debarring below 14 year olds from working in manufactures and states which have no such law to see if the law had an impact. What Moehling does is to add another layer of differencing by looking at the difference-indifference before and after some states adopted such legislation. This presumably nets out the effect that there may be differences between different states, stemming not from law but more inherent traits, such as industrial structure. Using national random samples of households from the censuses of 1880,1900 and 1910 and the method of DDD, Moehling concludes that minimum age restrictions had little impact on the employment in the US at the turn of the century.

The finding is important but not conclusive. For one, once one begins to go the route of adding on differences, strictly speaking, there is no stopping. Just as there may be innate differences between states, there may be innate differences (in particular, ones which are not the 
product of law) in changes over time across states.

Turning to the subject of state intervention, one must, in assessing the efficacy of a law, distinguish between the case where the law is not properly implemented and one in which the law is implemented but its net effect on society is not desirable. What Moehling's study points to is the inadequate inplementation of the US law. This does not mean that the law is not the right method of intervention for eradicating child labor. Another country at another time of history may be able to implement a law which had, allegedly, failed elsewhere in the late nineteenth century. An important policy question facing us is whether a legislative intervention is a desirable one? Does it promote welfare when properly implemented? To answer such questions it is essential to have a theoretical model for analyzing child labor. Later, when we have studied such models, we . will see that there is scope for using both legislative and non-legislative interventions. Policy towards child labor has to be more nuanced and context specific than what governments and international organizations have attempted. But before we get to such a conclusion it is useful to recapitulate what the major policy options are, and the role of different institutions.

\section{The Policy Questions}

In the battle against child labor a variety of laws and interventions have been tried and even more discussed. In recounting this debate, it is useful to distinguish between three kinds of interventions and institutions: intra-national, supra-national and extra-national.

Intra-national effort consists of the laws that a country enacts and interventions that it plans in order to control child labor within the national boundary. This invariably comes with a certain amount of institutional paraphernalia, such as organizations set up to administer the law 
and otherwise dissuade child employment. Contrary to the popular view, the question is not just between banning and not banning child labor. Instead a range of different instruments have been tried. This varies from one of the earliest pieces of legislation, such as the child labor law enacted by the state of Massachusetts, USA, in 1837, which prohibited firms from empioying children under the age of 15 years, who had not attended school for at least three months in the previous year, to contemporary laws such as Nepal's The Labor Act, 1992, and The Children's Act, 1992 that place restrictions on indigenous child labor ${ }^{12}$. Many countries also have important nongovernmental, intra-national efforts to curb child labor. The Daughters' Education Programme (DEP) in northern Thailand is one such effort. DEP tries to prevent little girls from going into prostitution by providing education and mobilizing local opinion. Literacy programs and compulsory education, to the extent that these get in the way of labor, may also be viewed as an intra-national intervention. I return to the subject of education below.

Supra-national interventions are those attempted through international organizations, such as the ILO, the WTO, and the UNICEF, which by establishing conventions, and encouraging and cajoling nations to ratify them, have tried to curb child labor. The most powerful, and also controversial, instrument that the supra-national institutions can use to curb child labor is the imposition of 'international labor standards', that is, a set of minimal rules and conditions for labor which all countries are expected to satisfy. Since the adoption of such standards makes it possible to take punitive action (such as imposing trade sanctions) against defaulting nations, these can be potentially quite effective. Labor standards are discussed in Section 8.

${ }^{12}$ The Children's Act, 1992, prohibit children of age 13 years or less from doing any work as employed laborers. The Labor Act, 1992, place restrictions of the kind of labor that children can do in 'enterprises' that employ ten or more persons (ILO, 1995). 
Thanks to controversy and a divergence of opinion the world has been slow to adopt international labor standards. This has led some developed countries to consider legislation and other action in their own countries which could curb child labor in developing nations. Such actions are what I label as extra-national. Consider, for instance, the Child Labor Deterrence Act, or the so-called "Harkin's bill", which has been debated extensively in the US Congress. In a nutshell this is a law that seeks to disallow the import into the US of goods that have been produced with the help of child labor. The law will work within the US but is nevertheless expected to have a strong deterrent effect in developing countries. There are variants of the Harkin's bill which have been considered and debated in the US. The "Sanders' amendment", which seeks to amend the Tariff Act of 1930 so as to deter the import of goods produced by unfree or bonded child labor, is another (and, to me, a more reasonable) example of extra-national intervention, as are recent efforts to have imported goods which are "child labor free" to be labeled as such.

The trouble with such extra-national interventions is that these can come to be misused by lobbies and protectionists representing narrow, sectarian interests. It is possible to take different views about the original motivation behind a bill. Alan Krueger (1997), for instance, did an unusual test of the hypothesis that it is protectionism that prompted the Harkin's bill (see also Dani Rodrik, 1997). His study was based on checking what kinds of constituency the sponsors of the bill come from; and he concluded that the motivation for the bill was humanitarian concern. On the other hand, while the recent versions of the Harkin's bill have no mention of trade and protection, giving the impression of its only concern being the humanitarian one regarding the plight of children, an early version of the bill had openly appealed that adult workers in the United 
States and other developed countries should not have their jobs imperiled by imports produced by child labor in developing countries (United States Department of Labor, 1992, p. 5; see also Basu, 1994; and Harkin, 1994) ${ }^{13}$. Fortunately, the original motivation is not the relevant question. What one has to be aware of is that such laws can be misused by the forces of protection.

An intra-national intervention which deserves to be discussed separately, is education and compulsory schooling. Historically this has been considered a major instrument for eradicating child labor. The relation between education and child labor has been an area of active empirical investigation. ${ }^{14}$ The important finding is that not only are these not mutually exclusive activities but there may be important complementarities between them. Thus, while Psacharopoulos' (1997) study, using household survey data from Bolivia and Venezuela, shows that though working children contribute substantially to household incomes, the educational attainment of children who work is significantly lower than that of non-working children, Patrinos and Psacharopoulos' (1997) research using Peruvian data reveals that child labor is not detrimental to schooling and leave the authors wondering if in some cases "working actually makes it possible for the children to go to school" (p.398). Presumably they are referrring here to part-time work which leaves children the time to go to school. Hence, a restricted amount of child labor and schooling can actually be complementary. This is especially true in rural areas and the urban informal sector where work hours are not rigid. In his study of child labor in rural Bengal, Maharatna (1997)

${ }^{13}$ Subsequently, the text of the bill (version of April 17, 1997) has changed further and this time in the right direction. It now tends to isolate child labor performed "under circumstances tantamount to involuntary servitude" or "under exposure to toxic substances or working conditions otherwise posing serious health hazards" as the kind against which the import restriction in the US will principally apply.

${ }^{14}$ For instance, Jensen and Nielsen (1997), Grootaert (1998) and Psacharopoulos (1997). 
found that male (female) children, aged 10-15, worked on average 7.78 hours (4.59 hours) a day, and of that only 3.01 hours ( 0.01 hours) were spent on formal wage employment. The importance and possibility of work-and-school among the very poor is also brought out well in Grootaert's impressive empirical study of child labor in Cote d'Ivoire. This does not detract from the fact that compulsory education can play a role in limiting child labor (Weiner, 1991). Morever, even if the education is not compulsory, the mere availability of good schools can do a lot in diverting children away from long hours in the work place (Dreze and Gazdar, 1996; Addison et al, 1997).

In debating policy questions, in particular the choice between compulsive measures, such as legal bans and compulsory education, it has to be kept in mind that for a child to work is not the worst thing that can happen. So when we stop child labor, there must be reason to believe that this will not make children worse off, for instance, by causing starvation or bodily harm ${ }^{15}$.

Even if legal intervention in the child labor market is found to be undesirable, this does not mean government should sit back and wait for natural economic growth to gradually remove children from the labor force. Government can intervene in the market to create a variety of incentives, such as providing better and more schools, giving school meals and improving conditions in the adult labor market, which result in a reduction of child labor.

The justification for a lot of these interventions depends on whether we believe that the state is more concerned about the well-being of children than are the parents of the children. I believe that such a presumption would be wrong when child labor occurs as a mass phenomenon as distinct from cases of isolated abuse. This is not to deny that there are contexts where legal

\footnotetext{
${ }^{15}$ A similar point has been made by Sarah Bachman (1995, p.3), who observed that attempts to bar children from working in the manufacturing sector in Bangladesh have pushed some of them over to prostitution.
} 
bans, total or sectoral, are desirable. But one needs careful, theoretical analysis to identify the contexts where these are likely to be beneficial.

\section{Early Theoretical Ideas}

Given the widespread prevalence of child labor in the last century it is not surprising that the origins of our contemporary mathematical models and theoretical constructs can be found, albeit in a much more primitive form, in the contributions of earlier writers such as Karl Marx, Alfred Marshall and Arthur Pigou.

Marx, writing at a time when the incidence of child labor in factories was at a peak, had a lot to say on the subject. Focusing here on the theoretical ideas it is interesting to note how Marx in (apital (Volume 1, Chapter 15, Section 3) virtually outlined a formal model of the cause of child labor. He first noted how, with the rise of new technology, in particular machinery, there arose scope for employing those "whose bodily development is incomplete, but whose limbs are all the more supple. The labor of women and children was, therefore, the first thing sought by capitalists who used machinery" (Marx, 1867, p. 372).

The availability of machinery can, in an ideal world, create more time for leisure. But Marx noted that since the machinery was owned by one agent and labor by another, a diminished need for labor would tend to depress wages ${ }^{16}$. So much so that (1) it may be worthwhile for the capitalist to use labor liberally and (2) it may be necessary for workers to have their entire family work in order to make ends meet. Marx $(1867$, p. 373) writes: "[Machinery] thus depreciates [the

${ }^{16}$ Empirical investigations cast doubt whether average wages did fall during this period. However, in certain sectors, such as the handloom, this was certainly the case (Lyons, 1989). 
man's] labor power. ... In order that the family may live four people must now, not only labor, but expend surplus-labor for the capitalist". This argument is very close to ideas that we pursue later; and can give rise to the possibility of multiple equilibria, as shown in Section $6 \mathrm{~A}$.

Marx also noted the long-term debilitating consequences of child labor. ${ }^{17}$ But it was Marshall who pursued this idea, to the point of sketching a dynamic argument. Marshall (1920, p. 620), with his characteristic fastidiousness, observed that children had labored even before the industrial revolution "but the moral and physical misery and disease caused by excessive work under bad conditions reached their highest point in the first quarter of the [nineteenth] century". He noted (p. 469) that "the most valuable of all capital is that invested in human beings".

Most interestingly, he showed awareness of the dynamics of these observations: "The less fully [the children's] faculties are developed, the less will they realize the importance of the faculties of their children, and the less will be their power of doing so. And conversely any change that awards to the workers of one generation better earnings, together with better opportunities of developing their best qualities, will increase the material and moral advantages which they have the power to offer to their children" (Marshall, 1920, p. 468).

Some of the features of this quote will be captured in a formal model in Section 6D. On policy, most early writers ranged from favoring a ban on child labor to placing severe restrictions on the quantity and quality of child labor. Pigou (1962), who favored a ban, was aware that a ban could cause poor families to dip below their subsistence level and so argued that a ban should be coupled with social welfare being provided by the state to the neediest families.

\footnotetext{
${ }^{17}$ On a matter of policy Marx was against a total ban on child labor for the Europe of his time. He favored restrictions on working hours and compulsory education (Marx, 1875).
} 
He did not tell us what his prescription would be if such social welfare was not forthcoming.

On what theoretical grounds did these early writers support government intervention in this matter? As we shall see later, more formally, there is a host of possible arguments; but for a long time the most popular has been that of 'externalities'. Keeping a child away from education may mean missing out on benefits for society at large which do not accrue to the parent who takes the decision. For one, the main benefit goes to the child. As Marshall (1920, p. 470) noted: "Whoever may incur the expense of investing capital in developing the abilities of the workman, those abilities will be the property of the workman himself: and thus the virtue of those who have aided him must remain for the greater part its own reward". John Stuart Mill also stressed the positive externality of education, arguing that for a parent not to educate the child is a breach of duty not only towards the child but "towards the members of the community generally, who are all liable to suffer seriously from the consequences of ignorance and want of education in their fellow citizens" (Mill, 1970, p. 319). By extension, he concluded (p. 323): "Children, and young persons not yet arrived at maturity, should be protected ... from being over-worked. Laboring for too many hours in the day, or on work beyond their strength, should not be permitted".

Externalities are such a well-known argument for intervention that it is often used too cavalierly by economists and non-economists. It is frequently used as a facade when the real reasons are more self-serving. In the context of child labor the externality argument needs to be made carefully for it to command attention. An excellent statement of this occurs in the recent work of Grootaert and Kanbur (1995). Grootaert and Kanbur consider the possibility that the social returns to education may exceed private returns. So government intervention to direct children away from work and to the classroom may be desirable. The ideal policy for achieving 
this, according to them, is to bolster the returns to education. They consider a ban on child labor to be a second-best intervention.

An extreme case of externality arises in the model of Gupta (1998) in which there is a total bifurcation between agency and welfare, since parents and employers take the child employment decision entirely in their self-interest. The child is simply an instrument of their bargain. The model in part B of the next section may therefore be viewed as a model of extreme externality.

\section{Bargaining Models}

The formal analysis of child labor is closely related to the modeling of household behavior. The early ventures in this direction (for instance, Rosenzweig and Evenson, 1977; Goldin, 1979) were models of household decision-making, which tried to simultaneously explain decisions of consumption and child labor and, at times, also child schooling and fertility. The specifications were kept simple enough to allow for this greater generality and also to allow for empirical testing. Subsequent work moved away from this to allow for the possibility that an household's behavior is not determined by one benevolent dictator, but instead is the outcome of internal bargains and power struggle. Models involving bargaining can and have been used to explain child labor and the level of well-being of children, though by and large such efforts treat child labor not as the focus of analysis but a fall-out of general household modeling. In this section, I present the main outline of these models, focusing on and drawing out their implications for child labor.

Bargaining models of child labor may be classified into two distinct kinds, depending on who the agents involved in the bargain are. According to one view, the bargain occurs within the 
family, between the parent and the child. The other approach treats the employer and the parent $\mathbf{s}$ of the child as the agents involved in bargaining. ${ }^{18}$ These two models are the subject matter of the next two subsections, respectively.

\section{A. Intra-household Bargaining}

The traditional model of the household, known as the unitary model, characterizes the household as a single unit of decision making (Becker, 1964). This is a valid model if one person in the household happens to be a dictator or all persons have the same utility function.

There is however increasing evidence that a household's consumption pattern tends to change as the composition of who earns how much changes even when the total earnings of the household is unchanged (see, for example, Thomas, 1990; Strauss and Thomas, 1995; and Moehling, 1995). This is usually taken to indicate that the household is not a single conflict-free unit of decision making but, instead, an area of bargaining, where a person's bargaining power depends on the resources one brings to the household and one's fall-back options. ${ }^{19}$

A general representation of these approaches occurs in what is known as the collective model (Bourguignon and Chiappori, 1994). Moehling (1995) has adapted this model further by taking explicit account of the child. For a simple version of this model, we could think of the household as being characterized by one parent (agent 1) and one child (agent 2). Since I am here

${ }^{18}$ These studies, therefore, exclude the case of "street children" who live on their own and belong to no household as such. The present paper also does not address the problem of homeless children. This is, however, not a negligible category (see Myers, 1988).

${ }^{19}$ See, for instance, Manser and Brown, 1980; McElroy and Horney, 1981; Folbre, 1986; Sen, 1990; Browning et al, 1994; Grootaert and Kanbur, 1995; Udry, 1996; and Agarwal, 1997. 
not interested in the demand functions for different products, I shall assume that there is only one good in the economy and $x_{i}$ is the amount consumed by agent $i$. Let the unit of the good be chosen such that its price happens to be 1. As in Moehling's model, suppose each agent in the household is concerned about the consumption of all members of the household ${ }^{20}$ Let $u_{i}$ be person i's utility function.

The household's utility function is a weighted average of $u_{1}$ and $u_{2}$ where the weight attached to the parent's utility, $\alpha$, depends on the incomes of the parent and the child, denoted, respectively by $y_{1}$ and $y_{2}$. In other words, in a household's utility function who gets how much weight depends on who brings how much money ${ }^{21}$. Hence, in the collective model, the household's decision-problem is as follows.

$$
\operatorname{Max}_{\left\{\mathrm{x}_{1}, \mathrm{x}_{2}\right\}} \alpha\left(\mathrm{y}_{1}, \mathrm{y}_{2}\right) \mathrm{u}_{1}\left(\mathrm{x}_{1}, \mathrm{x}_{2}\right)+\left[1-\alpha\left(\mathrm{y}_{1}, \mathrm{y}_{2}\right)\right] \mathrm{u}_{2}\left(\mathrm{x}_{1}, \mathrm{x}_{2}\right)
$$

$$
\text { subject to } x_{1}+x_{2} \leq y_{1}+y_{2} \text {. }
$$

It is assumed that

$$
\begin{aligned}
& \frac{\partial \alpha}{\partial y_{1}} \geq 0, \frac{\partial \alpha}{\partial y_{2}} \leq 0, \frac{\partial u_{1}}{\partial x_{1}}>0, \frac{\partial u_{1}}{\partial x_{2}} \geq 0, \\
& \frac{\partial u_{2}}{\partial x_{1}} \geq 0, \frac{\partial u_{2}}{\partial x_{2}}>0 \text { and } 0 \leq \alpha \leq 1 .
\end{aligned}
$$

${ }^{20}$ It is worth stressing that the important special case of this model is where each person is concerned about his own welfare and the final household consumption and labor supply is entirely a consequence of the power of different individuals.

${ }^{21}$ In this model the household allocation is always Pareto efficient. The empirical validity of this is not uncontested (see Udry, 1996). 
Moehling estimates a closely-related model using household data from early twentieth century urban America and finds that working children receive a larger share of household resources than non-working children.

This model can be taken further to explain a child's participation in the work force. To see this note that, strictly speaking, members of a household consume not just goods and services but also leisure. For simplicity assume that the adult always works. Let $\mathrm{e}$ be the work done by the child, where e $\epsilon[0,1]$. The child's consumption of leisure is, therefore, 1 - e.

Given that each person's utility depends on $x_{1}, x_{2}$ and $e$, a natural extension of the above model is to think of the household as facing the following decision problem, which I shall call the "collective maximization problem":

$$
\begin{aligned}
& \underset{\mathrm{x}_{1}, \mathrm{x}_{2}, \mathrm{e}}{\operatorname{Max}} \alpha\left(\mathrm{y}_{1}, \mathrm{y}_{2}\right) \mathrm{u}_{1}\left(\mathrm{x}_{1}, \mathrm{x}_{2}, \mathrm{e}\right)+\left[1-\alpha\left(\mathrm{y}_{1}, \mathrm{y}_{2}\right)\right] \mathrm{u}_{2}\left(\mathrm{x}_{1}, \mathrm{x}_{2}, \mathrm{e}\right) \\
& \text { subject to } \quad \mathrm{x}_{1}+\mathrm{x}_{1} \leq \mathrm{y}_{1}+\mathrm{y}_{2} .
\end{aligned}
$$

This is however a more complicated problem than appears at first sight since the child's income, $y_{2}$, depends on the choice of $e$. Thus it is not clear that $y_{2}$ can be thought of as an exogenous variable.

There are two alternative routes that one can take from here. One way out of this is to treat $\alpha$ as a function of the price vector, as in Bourguignon and Chiappori (1994). Then, since the wage rate is a price, $\alpha$ will turn out to be a function of the wage rates of adults and children ( $\mathrm{w}_{1}$ and $w_{2}$ ) rather than $y_{1}$ and $y_{2}$. And of course the budget constraint will now be:

$$
x_{1}+x_{2} \leq w_{1}+w_{2}
$$

keeping in mind that the adult always works full-time. 
This gives us a straight-forward optimization problem, which avoids the complication of simultaneity. The empirical plausibility of this approach however seems open to question. It implies that a person's bargaining power in the household depends not on the person's actual share of the household income but on the wage that one could earn, if one worked full time. Sociological studies, on the other hand, suggest that a woman's bargaining power in the household is diminished if a woman does not do outside work (Riley, 1997).

A second way out of this difficulty is one which rectifies this weakness and assumes that a person's power depends on how much income the person actually brings to the household budget. This is, however, technically more complicated. Note that in the collective maximization problem the decision maker is, effectively, an amalgam of the members of the household with the preference of each member receiving some weight. Once the child's effort (or, for that matter anybody's effort) is thrown in as one of the variables over which a decision has to be reached, the weights that individuals receive (here captured by $\alpha$ and $1-\alpha$ ) depend on what decision gets taken. In other words, who the decision maker is, depends in part on what the decision is. Hence, the collective decision problem cannot be thought of as a normal-form game, since in such a game the players or the decision makers are primitives. One direction that one can pursue is to take $y_{2}$ as exogenous and have the household decide on $x_{1}, x_{2}$ and $e$; and then check whether we recover the same $y_{2}$. If we do, then we have a 'household equilibrium'.

In order to do this let us take a child's wage rate to be w. That is, a full unit of work by a child yields a wage of $w$. If a child works for $e$ units, his total income, $y_{2}$, is ew. It is assumed that, as far as the household is concerned, $w$ is given exogenously. With $y_{1}$ and $w$ given exogenously, we describe $\left(\mathrm{x}_{1}^{*}, \mathrm{x}_{2}^{*}, \mathrm{e}^{*}\right)$ to be a household equilibrium if $\left(\mathrm{x}_{1}^{*}, \mathrm{x}_{2}^{*}, \mathrm{e}^{*}\right)$ is the solution 
to the above collective maximization problem, with $\mathrm{y}_{2}=\mathrm{e}^{*} \mathrm{w}$.

This equilibrium is not necessarily unique, nor is it obvious that it always exists. The existence problem is best understood by converting the household's problem to a search for the fixed point of a correspondence.

Let $\phi=[0,1]-[0,1]$ be a correspondence defined as follows. Given any e' $\in[0,1]$, we can take $y_{2}=e^{\prime} w$ (recall $w$ is given exogenously). Now solve the collective maximization problem taking $y_{2}$ to be e'w (recall $y_{1}$ is given exogenously). All values of $e$ which are a part of such solutions is the set $\phi\left(\mathrm{e}^{\prime}\right)$. This is what defines the correspondence $\phi$. It is now plain that a household equilibrium exists if and only if $\phi$ has a fixed point.

Given that the maximand in the collective maximization problem need not be concave, $\phi$ need not be convex-valued and we are not able to use Kakutani's fixed-point theorem. Indeed it is possible to construct reasonable examples where $\phi$ has no fixed points. On the other hand, it is also possible to think of restrictions on the parameters which ensure that an equilibrium exists. One simple example of this is the textbook case of selfish individuals: Let us assume

$$
\begin{aligned}
& u_{1}\left(x_{1}, x_{2}, e\right)=f_{1}\left(x_{1}\right) \\
& u_{2}\left(x_{1}, x_{2}, e\right)=f_{2}\left(x_{2}\right)-c(e) .
\end{aligned}
$$

That is, the parent is interested in his own consumption, the child in the child's own consumption. It is worth emphasizing that this is still a collective model of the household, since the household's maximand continues to be a weighted average of the utilities of the members of the household. Hence, the allocation of resources continue to be Pareto efficient. Let us also, as is usual, assume, $f_{1}^{\prime}, f_{2}^{\prime}, c^{\prime}>0, f_{1}^{\prime \prime}, f_{2}^{\prime \prime}<0$, and $c^{\prime \prime}>0$.

These assumptions ensure that for every $y_{1}$ and $y_{2}$, there is a unique $\left(x_{1}, x_{2}, e\right)$ which 
solves the collective maximization problem, and that the solution varies continuously with $\mathrm{y}_{2}$. Thus, ignoring other variables, we can write $\psi\left(y_{1}, y_{2}\right)$ to be the value of e which solves the maximization problem, given $y_{1}$ and $y_{2}$. Since for every e $\epsilon[0,1], y_{2}=e w$, we can define $\phi(e)=\psi\left(y_{1}, e w\right)$. Since $\phi$ is a continuous function from $[0,1]$ to $[0,1]$, by Brouwer's fixed point theorem, there exists $\mathrm{e}^{*}$ such that

$$
\mathrm{e}^{*}=\phi\left(\mathrm{e}^{*}\right)=\psi\left(\mathrm{y}_{1}, \mathrm{e}^{*} w\right)
$$

$\mathrm{e}^{*}$ is the amount of labor that the child will be made to supply in equilibrium.

Note that $e^{*}$ can be written as a function of $y_{1}$ and $w$, by using (1). Thus

$$
\mathrm{e}^{*}=\mathrm{e}^{*}\left(\mathrm{y}_{1}, w\right)
$$

In other words, the child's labor supply depends on the adult wage $\left(y_{1}\right)$ and child wage $(w)$ that prevails on the market. It is possible to develop a more elaborate model with more exogenous variables. It will be interesting to draw out the empirical implictions of such a model and put them to test. Another direction that can be pursued is to model the interaction between household members as a sequential game in which a player's power in period $t$ depends on his income share in period $t-1$. Instead of pursuing this here, I shall instead move on now to discuss models which were developed explicitly to explain child labor. One such model is that of Gupta (1998).

\section{B. Extra-household Bargaining}

Citing a survey work currently afoot in some villages of West Bengal, India, Gupta (1998) argues that a child has negligible bargaining power in the household and is, effectively, an instrument for the parent's maximization effort. In addition, he assumes that parents are entirely 
selfish in the sense of being uninterested in the well-being of the children per se. While a parent owns his child's labor he is unable to make the child work productively for want of complementary resources, such as land or cattle. He found that in West Bengal villages the bulk of child labor is directed to the maintenance of cattle. So for work the child has to go to an employer, who has the resources.

The bargaining that occurs in this model is between the parent and the employer over (i) the wage, $w$, that is to be paid for the child's work and (ii) the fraction, $\lambda$, of the wage that is to be paid in the form of food to the child. Gupta (1998) assumes that the parents spend the cash component of the wage entirely on themselves. I believe that this is empirically questionable but let us go along with it as a simplifying assumption.

Using an efficiency wage argument, assume that the output, $\mathrm{x}$, produced by a child laborer is a function of his consumption. So

$$
x=x(\lambda w)
$$

where $x(\lambda w)=0$, for $\lambda w$ less than some positive number, $b$, and concave thereafter. That is, for all $\lambda w>b, x^{\prime}(\lambda w)>0$ and $x^{\prime \prime}(\lambda w)<0$.

Let us assume that if the bargain fails, the parent and the employer earn $Y_{P}$ and $Y_{E}$ respectively. Hence, the threat point, of the bargaining problem is given by $\left(\mathrm{Y}_{\mathrm{P}}, \mathrm{Y}_{\mathrm{E}}\right)$. If the parent and the employer agree on $(w, \lambda)$, their incomes are, respectively, $(1-\lambda) w$ and $x(\lambda w)-w$.

Therefore, the Nash bargaining problem consists of solving the following problem:

$$
\operatorname{Max}_{\{w, \lambda\}}\left[(1-\lambda) w-Y_{p}\right]\left[x(\lambda w)-w-Y_{E}\right]
$$

This gives us the first-order conditions: 


$$
\begin{aligned}
& {\left[(1-\lambda) w-Y_{P}\right] x^{\prime}(\lambda w) w-w\left[x(\lambda w)-w-Y_{E}\right]=0} \\
& {\left[(1-\lambda) w-Y_{P}\right]\left[x^{\prime}(\lambda w) \lambda-1\right]+(1-\lambda)\left[x(\lambda w)-w-Y_{E}\right]=0}
\end{aligned}
$$

By rearranging these we get:

and

$$
x^{\prime}(\lambda w)=1
$$

Since $\lambda w$ is, effectively, the child's wage, (2) says that the child's marginal product is set equal to 1 . This is the standard result of efficiency wage. To see this, use $v$ to denote a child's wage. Then the net income generated by a child is given by $x(v)-v$. If $v$ is chosen to maximize this, we get $x^{\prime}(v)=1$, which is exactly what (2) is. In other words, in this model a child is paid a wage, $\lambda w$, that maximizes net returns. The value of this is independent of the threat point. Once we know the value of $\lambda w$, we can use (3) to solve for the value of $w$. This depends on $Y_{P}$ and $Y_{E}$. As $\left(Y_{E}-Y_{P}\right)$ increases, $w$ falls and $\lambda$ increases, as is evident from (3).

It is now possible to derive comparative statics results by postulating how $Y_{\mathrm{E}}$ and $\mathrm{Y}_{\mathrm{P}}$ get set and considering variations of this. Gupta (1998), for instance, considers the case where $Y_{F}$ depends on the adult wage that prevails on the market. In particular, he assumes that $Y_{E}$ falls as adult wage rises. This implies that as adult wage rises, the child's wage, w, will rise.

One can however hypothesize other explanations for $Y_{\mathrm{E}}$ and $\mathrm{Y}_{\mathrm{P}}$ and derive other theories of how w will depend on the parameters of the model. What is interesting about this model is how sharply it contrasts with the model that we are about to encounter, one in which the parent is altruistically concerned about the child's welfare. In the model just described, the child's welfare is nobody's concern. The child is valued in the same way as the goose that lays the golden eggs. 


\section{Multiple Equilibria and Government Intervention}

What the early models seemed to overlook is that a labor market, where children are potential workers, will be prone to having more than one equilibrium, and if it did, then this would raise a variety of interesting policy questions. This is demonstrated in the model of Basu and Van (1998). It is worth asking why the model of Section 5A overlooked the possibility of multiple equilibria. Note that the collective maximization problem reduces to the unitary model of the household if (i) $u_{1}\left(x_{1}, x_{2}, e\right)=u_{2}\left(x_{1}, x_{2}, e\right)$, or (ii) $\alpha\left(y_{1}, y_{2}\right)=1$, for all $y_{1}, y_{2}$, or (iii) $\alpha\left(y_{1}, y_{2}\right)=0$, for all $y_{1}, y_{2}$. But in allowing for this generality what the model glosses over are some natural restrictions on the utility function, which is the starting point of the model of Basu and Van (1998). The latter is based on the unitary model. That is, it assumes that (i), (ii) or (iii) is valid, but this is not its distinguishing mark. I would conjecture that the model's central results would remain valid even if we allowed for bargaining within the household. A simplified model of Basu and Van is presented in subsection A. Subsections B-D discuss the relation between child labor and, respectively, social norms, adult unemployment and dynamics.

\section{A. Model with Altruism}

I shall here demonstrate, following Basu and Van (1998) but using some very special assumptions, the possibility of multiple equilibria. The special assumptions are for reasons of convenience. The only two essential assumptions are the following:

Luxury axiom: A household would not send its children out to work if its income from non-child labor sources were sufficiently high.

Substitution axiom: Adult labor is a substitute for child labor, or more generally, adults 
can do what children do.

To give the simplest sketch of this model, let me strengthen these two assumptions to assert that (1) for every household $i$, there exists a critical wage, $W_{i}$, such that the household will send its children out to work if and only if the adult wage prevailing in the market is less than $\mathrm{W}_{\mathrm{i}}$; and (2) adult labor and child labor are perfect substitutes subject to an adult equivalence correction. Both these assumptions can be relaxed enormously without hurting the conclusions of the model. Let us define $\overline{\mathrm{W}} \equiv \operatorname{Max}_{i} \mathrm{~W}_{i}$ and $\underline{\mathrm{W}} \equiv \min _{i} \mathrm{~W}_{i}$.

Suppose that a child's labor is equivalent to $\gamma$ units of an adult's labor, where $0<\gamma<1$. In other words, I am assuming that adult and child labor are perfect substitutes subject to an adult-equivalent scale correction of $\gamma .{ }^{22}$ A more convenient way of thinking of this is as follows. Production depends on the total amount of labor used; and each adult, working all day, produces 1 unit of labor, whereas each child, working all day, produces $\gamma$ units of labor.

In Figure 1, let the vertical axis represent adult wage (i.e. the wage paid to an adult for a full day's work). Consider a competitive model in which all agents are price takers. Let $\mathrm{AA}^{\prime}$ be the supply curve of the aggregate adult labor in the economy. For simplicity we show it as perfectly inelastic. Next consider the total amount of "effective labor" that all the children can supply. If there are $\mathrm{X}$ children in the economy, this will be equal to $\gamma \mathrm{X}$. Add to the aggregate

${ }^{22}$ Admittedly this is a simplifying assumption. What is really needed is the assumption that adults can do what children do. This is contrary to the pervasive, "nimble fingers" belief--that for some activities, such as carpet-weaving, children are essential. There is however very little empirical support for this belief (ILO, 1996). One of the most careful examination of this occurs in the study of India's carpet industry by Deborah Levison et al (1998). By collecting information on actual productivity--for instance, square inches knotted per hour--they reach the conclusion that for no activity are children essential. Adults can always replace them. This is not to deny that such substitution may cause costs to rise, since adult wages are typically higher. 
adult labor supply the effective labor that the children can potentially supply in the economy and draw another line representing this. Let $\mathrm{T}^{\prime} \mathrm{T}$ be this new line. Thus $\mathrm{A}^{\prime} \mathrm{T}$ is equal to $\gamma \mathrm{X}$, the total amount of labor available from the children in the economy. In other words, if the country had a law that everybody would always have to supply labor, then the aggregate supply curve of labor in the economy would indeed by T'T.

\section{Figure 1}

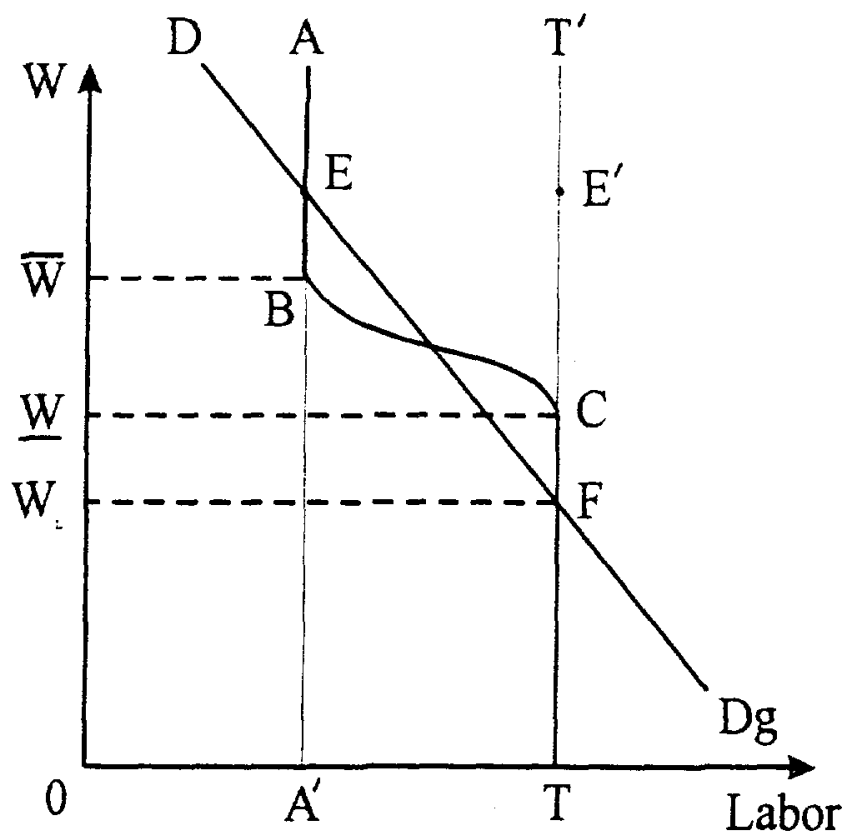


Now it is easy to figure out the actual, aggregate supply curve of labor. If the market (adult) wage is below $\underline{\mathrm{W}}$, then all children are sent to work; so total labor supply is OT. If the market wage exceeds $\overline{\mathrm{W}}$, no child is sent to work; so total labor supply is $\mathrm{OA}^{\prime}$. As wage rises from $\underline{\mathrm{W}}$ to $\overline{\mathrm{W}}$ one household after another withdraws its children from the labor force; so the total supply of labor keeps decreasing, as shown by the curve CB. Hence the total supply of all kinds of labor (that is, adult plus child) plotted against alternative adult wages gives us the curve $\mathrm{ABCT}$. Let me call this the 'hybrid supply curve'; which should serve as a reminder that it is not quite the standard supply curve

Not only is this supply curve backward-bending but its composition keeps changing as we move along its contour. Along $\mathrm{AB}$ it consists of pure adult labor; as we move from $\mathrm{B}$ to $\mathrm{C}$ it includes more and more child labor; and from $\mathrm{C}$ to $\mathrm{T}$ it consists of all available labor in the economy.

The possibility of multiple equilibria is now transparent. I shall now assume, without loss of generality, that whenever adult wage is $W$, child wage happens to be $\gamma W$. Keeping this in mind, suppose the aggregate demand curve for labor in the economy is given by $\mathrm{DD}^{\prime}$. That is, DD' shows the total effective labor demanded by firms for every possible adult wage $\mathrm{W}$. Then there are three equilibria ${ }^{23}$. Let us ignore the unstable one and focus on the ones depicted by $\mathrm{E}$ and $F$ in Figure 1. If an economy is caught at point $F$, wages will be low $\left(W_{L}\right.$ for adults and $\gamma W_{L}$ for children) and children will be working. The same economy, however, can be in equilibrium at

\footnotetext{
${ }^{23}$ An important exception is a sufficiently open, small economy, where wage would be determined by world prices, and so the demand curve would be horizontal, thereby destroying the multiple equilibria result (Dixit, 1998). Even in this case, however, there may be multiple equilibria in a dynamic sense as shown in section $6 \mathrm{D}$.
} 
point $\mathrm{E}$, where wages are high and children do not work.

If the economy is at equilibrium point $\mathrm{F}$, there is scope for an interesting policy intervention, which in Basu and Van's paper is called a "benign intervention". Suppose child labor is banned. Then effectively, the supply curve of labor becomes AA'. So if demand conditions are unchanged, the economy will now settle at the only equilibrium, at $\mathrm{E}$. What is interesting is that once the equilibrium settles at $\mathrm{E}$, the law banning child labor is no longer needed (since $\mathrm{E}$ was anyway an equilibrium of the original economy). It is in this sense that the intervention is described as benign. After its initial effect, it goes dormant and can actually even be removed without loss. ${ }^{24}$

If the demand curve intersects the supply curve only once and on the segment CT, then a ban on child labor may well cause a decline in welfare of the workers, including the child laborers. $^{25}$

If this model were fitted into a Walrasian description of the entire economy, each equilibrium would be Pareto optimal. So between the equilibria depicted by E and F neither Pareto dominates the other. However, working-class households are necessarily better off at E. To see this, consider a (call it E'), where wages are the same as at $E$ but all children work. Clearly

\footnotetext{
${ }^{24}$ The model also is suggestive of the link between technology and child labor. If technology changes so that children become relatively less productive than adults (perhaps because of the rise of the use of the computer), then we could think of $\gamma$ as falling. From Figure 1 it is clear that this would result in T moving left and the inferior equilibrium, where children work, vanishing.

${ }^{25}$ Arguing from a different perspective Jacoby and Skoufias $(1997$, p.331) reach a similar conclusion: "... our results suggest that efforts to expand educational opportunities for the poor [...] without an understanding of the economic risks and constraints they face may be met with only limited success. Moreover, compulsory schooling laws or laws against child labor, to the extent that they can be enforced in rural areas, could substantially lower household welfare."
} 
worker households are better off at $E^{\prime}$ than at $F$ since in both cases everybody works but in the former the wages are higher. Next, since given the wages at $E$ households prefer not to send the children to work, by revealed preference we know that $E$ is superior to $E^{\prime}$. Hence, by transitivity $E$ is preferred to $F$.

The contestable assumption of this model is the luxury axiom, which takes for granted parental altruism towards the child. In the early nineteenth-century, when child labor took some of its worst forms in industrializing Europe, a standard critique of the British elite was that child labor was an outcome of parental callousness (see Nardinelli, 1990, p.94). There is however counter-evidence, including from those who themselves worked as child laborers, that the parents sent their children out to work typically when they were compelled to do so by acute poverty (Anderson, 1971; Vincent, 1981).

Turning to more contemporary evidence, Burra (1995) has reported evidence of parental callousness; and Gupta (1998) has cited sources which support this viewpoint (see also Parsons and Goldin, 1989). The much discussed issue of discrimination against the female child in several developing regions, notably in northern India, suggests that the answer may also differ depending on whether we are talking of the male child or the female child ${ }^{26}$ In addition, a study by Alaka Basu (1993) of some slums outside New Delhi brings to light another perverse causation between adult wages and child labor. When the wage for female laborers rise, starting from a sufficiently low level, this often prompts the mother to take up work outside home, which in turn means that

\footnotetext{
${ }^{26}$ The source of this discrimination need not be household. If job opportunities for females are limited, it may be a rational response of the household to first educated the boys before turning to the girls. In the context of adults, the more puzzling possibility of gender discrimination in the labor market originating from within the household is modeled elegantly by Francois (1998).
} 
she takes the daughter out of school in order to have her do the house work. It is arguable that if the mother's wage rises sufficiently, the daughter would get put back into school with household help now being hired from outside. This suggests an inverted- $U$ relation between adult female wage and child labor, especially the labor of the female child.

A recent empirical test of the luxury axiom, by Ranjan Ray (1998), suggests that the verdict is mixed. He uses data from Peru's Living Standards Measurements Survey, 1994, and Pakistan's Integrated Household Survey, 1991, to check if the luxury axiom is valid. For this test he constructs a dummy variable which takes a value of 1 for households with income below the poverty line and 0 otherwise, and then then uses probit and logit models to test the importance of this status on the household's decision to send its children to work. The estimated coefficients lend support for the luxury axiom in Peru but not in Pakistan. While these tests may be interesting in their own right, they do not really test the luxury axiom, because Ray identifies $W_{i}$ entirely with the poverty line, whereas nowhere does the axiom suggest that this should be so. What does come out rather interestingly from Ray's paper is, as in Basu (1993), the differential response of child labor to changes in the mother's and the father's wages.

One of the best crafted empirical studies of child labor is Christiaan Grootaert's (1998) work on Cote d'Ivoire. It is based on annual data collected for 1600 households over the years 1985 to 1988 . Sorting out carefully various definitions, he goes on to use a sequential probit model to find the determinants of child labor. He corroborates that the characteristics of the parents matter and also that who has these characterisitcs, the father or the mother, matters. It is evident from his study that the very poor households often critically rely on the children's income and leads him to conclude that, initially, interventions should aim to make possible combining 
light work with schooling, instead of a sudden stoppage of child labor.

This is not the forum to settle this controversy but to pursue the consequences of alternative viewpoints. The extreme case in which parents have no altruism or commitment towards the children but treat them purely as labor-producing machines was modeled in Section 5B. My own preference is for the altruistic model of this section, while admitting that it is best viewed as a polar characterization of reality. For a clearer conclusion we will have to wait for further econometric work.

\section{B. Norms}

With the idea of multiple equilibria in the core there are several directions that one can pursue. Albert Hirschman ${ }^{27}$ has rightly argued that the decision to send a child to work is partly a matter of social norm. ${ }^{28}$ This may be made more precise by assuming that sending a child to work makes the parents incur a social stigma cost, c; and if many children work, then $\mathrm{c}$ is smaller. The latter captures the idea that while making a child work is socially frowned upon, the ferocity of the frown is greater if you live in a society where virtually no one sends their child to work but you do. This can yield the result that if everybody sends their child to work, it is worthwhile for each parent to send his child to work and if everybody does not send their child to work, each parent may find it not worthwhile to send his child to work (because the social stigma would be too high). The argument here is analogous to the one used by Lindbeck, Nyberg and Weibull

${ }^{27}$ Personal communication to the author dated 15 February, 1995.

${ }^{28}$ “Social norm" has many interpretations (Basu, 1998, Dasgupta, 1993). I use it here as a social influence that changes our preference. The relation between child labor and cultural norms has been discussed in the book by Rodgers and Standing (1981), especially in chapter 1. 
$(1998)^{29}$ to show how the number of people who are unemployed and live off social welfare can settle at very different values depending on which of the possible multiple equilibria is realised.

This is a simple point analytically but is probably of considerable practical importance in the context of child labor. Also this is an idea that can, potentially, be developed much more and used to address questions of policy.

\section{Distribution and Unemployment}

In the model of section $6 \mathrm{~A}$ workers are assumed to be ex ante identical and in the equilibrium that occurs they turn out to be ex post identical. A coisequence of this is that the model is completely silent on questions of income distribution and unemployment. The literature has relatively little to offer on these topics. The distribution question is raised in a short theoretical paper by Swinnerton and Rogers (1998); there is little that is available on this empirically. On the other hand, the relation between adult unemployment and child labor has been the basis of some empirical investigation (see Goldin, 1979; Horan and Hargis, 1991; Bonnet, 1993; Chandrasekhar, 1997); the hiatus here is in the theory. Modeling the relation theoretically is a large and interesting topic but some initial steps towards it are easy to take using the model of section A above ${ }^{30}$ Before doing so, I want to briefly recount Swinnerton and Rogers' argument.

Their paper begins with the observation that if a parent's decision to send the children to work depends on (among other things) the parent's income, then we should look at not just the (1992).

\footnotetext{
${ }^{29}$ For the use of similar assumptions, see Granovetter (1978), and Besley and Coate
}

${ }^{30} \mathrm{~A}$ different model linking adult unemployment with child labor occurs in Gupta (1997). 
parent's wage but also any profits that may accrue to the parents. So they move away from the polar assumption of Basu and Van's model by supposing that the firms are owned by a fraction $\lambda$ of the workers. So for workers in this category income equals wages plus a share of profits, while the remaining workers earn only wages. They then show that, if in an economy there exists a good equilibrium, then there does not exist an equilibrium in which the dividend-earning workers send their children to work. This directs the policy discussion to matters of distribution. Giving workers a share in profits turn out to be a method of curbing child labor. This is a valid argument, though the feasibility of such policy changes may be restricted for reasons of politics.

Turning to the subject of adult unemployment, let us suppose that there are $\mathrm{N}$ worker households and each household has one adult and $\mathrm{m}$ children. As before, child non-work is a luxury good and, in particular, for each household i there is a critical adult wage $W_{i}$ such that if the adult wage rises above $W_{\mathrm{i}}$, the household withdraws its children from working. Adults, on the other hand, always prefer to work, no matter what the wage. This immediately gives us the aggregate labor supply curve as in figure 1 .

As before, let us assume that one child manages to produce the equivalent of $\gamma$ units of adult labor. Hence if the prevailing market child wage, $W_{c}$, happens to be equal to $\gamma \mathrm{W}$, where $\mathrm{W}$ is the prevailing market adult wage, then firms will be indifferent between employing adults and children. Let us focus on the case where $\gamma W=W_{c}$. I should clarify that I am not assuming $W_{c}$ to be exogenously fixed. Rather I am trying to isolate an equilibrium in which $\mathrm{W}_{\mathrm{c}}$ happens to be equal to $\gamma W$.

Within the confines of this case we can think of the total effective demand for labor to be a function of $\mathrm{W}$. Let us denote such an aggregate demand function by $\mathrm{d}(\mathrm{W})$. Let us assume that this 
is downward-sloping and take DD' in figure 1 as representing such a demand curve.

To study the impact of adult unemployment on child labor, we first need a model in which there can exist adult unemployment. The best way to develop such a model is to use some model which can endogenously explain wage rigidities. I shall, however, for reasons of simplicity, stay away from such complications ${ }^{31}$ and simply assume that adult wage is exogenously fixed at $\mathrm{W}^{*}$, where $\mathrm{W}^{*}$ is such that $\mathrm{d}\left(\mathrm{W}^{*}\right)<\mathrm{N}$. In other words, we are focusing on cases above point $\mathrm{E}$ in figure 1. The questions are: How many adults will find employment? Will children be working and if so what will be the incidence of child labor?

In answering these questions I shall consider the case where $\gamma \mathrm{m}<1$ and $d\left(W^{*}\right)-\gamma \mathrm{mN}>$ 0 . This is merely a sufficient condition for the existence of an equilibrium in which $\gamma W^{*}=W_{\mathrm{e}} . A$ fuller model will have to go beyond this and consider other cases as well, but the logic of the relation between child labor and adult unemployment comes out clearly even in this limited model.

Let us use $\mathrm{E}$ to denote the number of adults that will find employment. Since the total demand for labor is $d\left(W^{*}\right)$, it follows that $d\left(W^{*}\right)$ - E will be the amount of labor demanded from children. In other words, the number of children demanded by the firms will be $\left[d\left(W^{*}\right)-E\right] / \gamma$. Since child wages are not rigid, demand for child labor must be equal to supply of child labor. So what remains to be done is to determine the supply of child labor. Note that if only $E$ adults find employment, $\mathrm{N}$ - E households will be earning zero income from the adults. So these will be the households that will send the children out to work. Hence, if E adults find work, the supply of child labor will be given by $\mathrm{m}(\mathrm{N}-\mathrm{E})$. In other words, $\mathrm{E}$ is equilibrium adult employment if:

$$
m(N-E)=\left[d\left(W^{*}\right)-E\right] / \gamma
$$

${ }^{31}$ For a model of child labor and efficiency wage see Genicot (1998). 
To remind ourselves that the value of $\mathrm{E}$ depends on $\mathrm{W}^{*}$, let us write the solution of this equation as $\mathrm{E}\left(\mathrm{W}^{*}\right)$. Evidently,

$$
E\left(W^{*}\right)=\left[d\left(W^{*}\right)-\gamma \mathrm{mN}\right] /(1-\gamma \mathrm{m})
$$

Since $\mathrm{d}($.$) is a downward sloping function, it follows that as \mathrm{W}^{*}$ rises, adult employment, $\mathrm{E}\left(\mathrm{W}^{*}\right)$, will fall.

If we use $\mathrm{C}\left(\mathrm{W}^{*}\right)$ to denote the number of children who find employment, when adult wage is fixed at $\mathrm{W}^{*}$, then we have:

$$
C\left(W^{*}\right)=m\left[N-E\left(W^{*}\right)\right]=m\left[N-d\left(W^{*}\right)\right] /(1-\gamma m) .
$$

Given that we are considering the case where $\gamma \mathrm{m}<1$, it follows that $\mathrm{C}\left(\mathrm{W}^{*}\right)>0$. Further, as $\mathrm{W}^{*}$ rises, $\mathrm{C}\left(\mathrm{W}^{*}\right)$ rises. Since a rise in $\mathrm{W}^{*}$ increases adult unemployment, a rise in adult unemployment is associated with an increased incidence of child labor.

This confirms intuition and empirical findings but also cautions us about the right policy intervention $^{32}$. If market wages rise, we have good reason to believe that child labor will decline, but that does not mean that this impact on child labor can always be replicated by raising adult wages by fiat. If the adult labor market has oligopsonistic elements, a rise in the legal minimum wage can boost adult employment and cause a decline in child labor, but in competitive labor markets one will have to rely on interventions which boost adult wage by shifting the equilibrium.

\section{Dynamics}

One big caveat in the large literature on child labor is the treatment of dynamics. Yet the

${ }^{32}$ The model also allows us to derive some theoretically puzzling results, such as how the abolition of a legal minimum wage can cause wages to rise. To see this start from a minimum wage, $\mathrm{W}^{*}$, below point $\mathrm{E}$ in Figure $\mathrm{I}$ and derive the equilibrium as done above. 
dynamic consequences of child labor are likely to be large since an increase in child labor frequently causes a decline in the acquisition of human capital. If a child is employed all through the day, it is likely that the child will remain uneducated and have low productivity as an adult.

While the analysis of the long-run consequences of child labor is almost totally ignored in the literature (Baland and Robinson, 1998, being an exception), one can draw on some papers on human capital acquisition and its long-run consequences, a la Galor and Zeira (1993), Banerjee and Newman (1993) and Ljungqvist (1993) to derive some hints for modeling the dynamics of child labor ${ }^{33}$. This is what I attempt here and in the process develop the idea of a "child labor trap". I use some strong assumptions to develop my argument but it should be possible to relax these.

Since my aim is to explain multiple equilibria in the long-run, it cannot be criticized if I make an assumption which tilts the description of the single-period model away from multiple equilibria. Note that in Figure 1, if the demand curve is sufficiently elastic, there will exist only one equilibrium in the single-period model. To ensure that this is the case, I shall assume that the demand for labor is perfectly elastic.

Consider an overlapping generations model in which each person lives for two periods, first as a child and then as an adult; and at the start of the second period gives birth to a child. As a child a person can either work or go to school (that is, acquire human capital). So if we denote a full day by 1 and a child works for a fraction e of the day, then the amount of human capital acquired by the child is $1-\mathrm{e} \equiv \mathrm{h}$.

${ }^{33}$ For an overlapping generations model of parental schooling decisions, with implications for child labor, see Glomm (1997). 
The productivity of an adult depends on the amount of human capital, $h$, he acquired as a child. If we think of $\mathrm{L}$ as the number of labor units produced by one adult, then what we are assuming is that

$$
\mathrm{L}_{\mathrm{t}}=\mathrm{L}\left(\mathrm{h}_{\mathrm{t}-1}\right), \quad \mathrm{L}^{\prime}>0, \mathrm{~L}^{\prime \prime}<0 .^{34}
$$

Let us make the normalization assumption that $L(0)=1$. In other words, the amount of labor produced by an unskilled adult is defined to be 1 . That there is an inverse relation between child labor and the child's productivity in later life is also assumed by Parsons and Goldin (1989), though they do not pursue the long-run consequence of this assumption.

Let us use $V$ to denote the wage of one unit of labor. If labor demand is perfectly elastic, this will be constant and so we take the wage rate to be fixed at $V$. Hence, in period $t$, an adult who as a child, that is, in period $t-1$, had worked $e_{t-1}$ amount, will have an income of

$$
\overline{\mathrm{VL}}\left(1-\mathrm{e}_{\mathrm{t}-1}\right) \equiv \mathrm{W}_{\mathrm{i}} \text {. }
$$

As is the model of subsection $\mathrm{A}$, we assume that it is the parent who decides whether to send a child to work. Let us assume that there is a wage $\underline{\mathrm{W}}$ such that, if adult income is below

${ }^{34}$ So we are assuming that if a child works more, his productivity as an adult falls. We justify this by assuming that a child's nonworking time is spent on studying. Even without this assumption one can argue that child labor diminishes adult productivity. As Pigou (1920, p. 751) had noted, "Many forms of unskilled labor at present open to boys not merely fail to train, but positively untrain, their victims". Swaminathan's (1997) study of child labor in Gujarat, India, weakly confirms this. She found that for boys entering the labor force as a child lowered productivity when they became adults, though for girls there was no significant effect one way or the other. It is however noteworthy that in some special cases this relation tends to go the other way. The English cotton mills of the last century may be a case in point. Galbi (1997) has argued that the share of child labor in the mills fell during the early nineteenth century precisely because the earlier rise in child labor meant that, as these children grew up, there would be a cohort of more productive adult workers. 
$\underline{W}$, the parent sends the child to work full time, that is $\mathrm{e}=1$. Let us also assume that there is a wage $\bar{W}>\underline{W}$ such that, if adult income exceeds $\bar{W}$, he does not send his child to work at all, that is, $\mathbf{e}=0$. Unlike in the model of subsection $\mathrm{A}$, we take all adults to be identical and assume that the child's labor is not a $0-1$ decision but monotonically varies with the parent's income. This may be summed up by assuming that the amount of work that a child is made to do in period $\mathrm{t}$ is a function of the parent's wage in period $t$ :

$$
e_{t}=e\left(W_{t}\right)
$$

such that $e(W)=1$, for all $W \leq \underline{W} ; e(W)=0$, for all $W \geq \bar{W}$; and $e^{\prime}(W)<0$, for all $W \in(\underline{W}, \bar{W})$.

From (5) and (6) we get

$$
e_{t} \equiv e\left(\bar{V}_{L}\left(1-e_{t-1}\right)\right)
$$

which may be described in brief as

$$
\mathrm{e}_{\mathrm{t}} \equiv \phi\left(\mathrm{e}_{\mathrm{i}}\right)
$$

From the assumptions made above we know that $\phi$ is upward sloping and bounded above at $e(\bar{V} L(0))=e(\bar{V})$. In order to focus on the interesting case we consider an $\phi$ which intersects the $45^{\circ}$ line more than once. In the case illustrated in Figure 2, there are three steady-state equilibria, of which two are stable. These are depicted by points 0 and $E$. At $E$, a poor parent makes the child work full-time. The child acquires no skills and so as an adult earns very little and has to send his child, in turn, to work full-time. This equilibrium depicts what may be called a 
"child labor trap". ${ }^{35}$ On the other hand 0 depicts an equilibrium where a child goes to school, earns adequately as an adult and so can and does send his child to school. It is a virtuous cycle. ${ }^{36}$

Figure 2

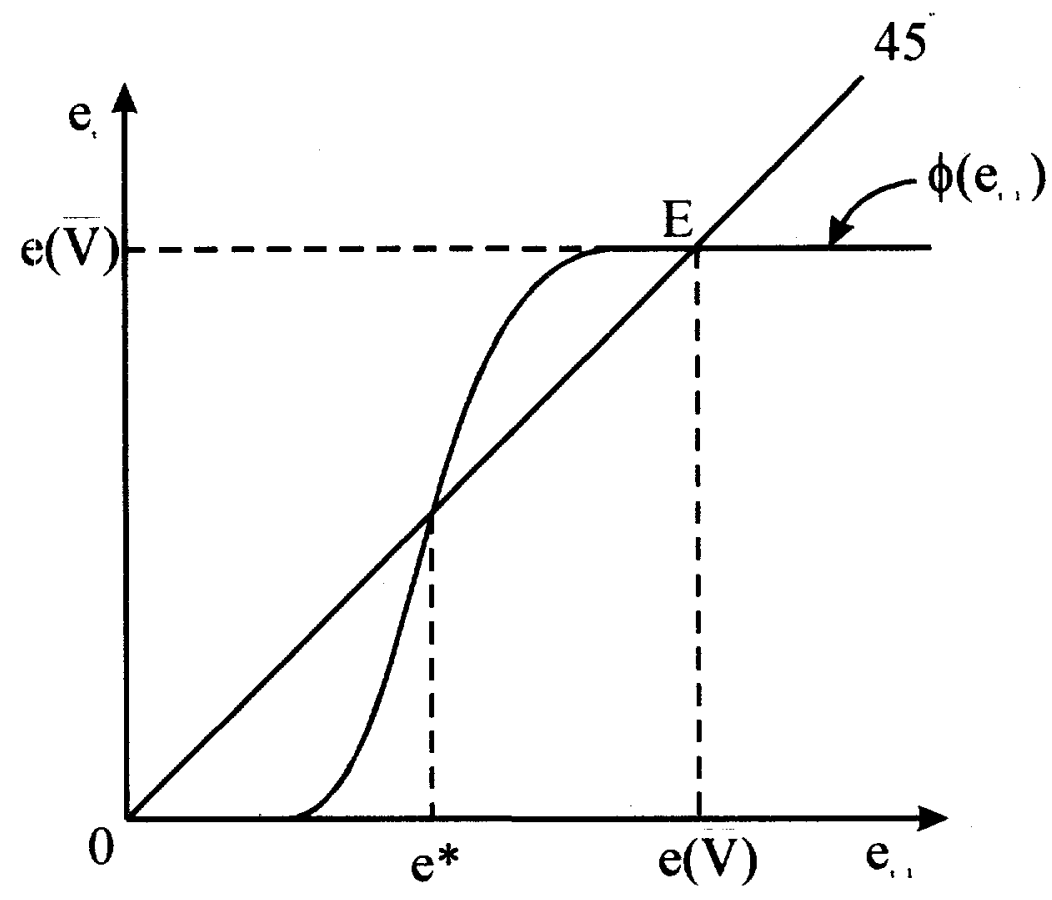

${ }^{35}$ A different kind of trap has been modeled by Eswaran (1996). In his framework the existence of the institution of child labor biases parents towards having more uneducated children rather than a few educated children. And this choice in turn perpetuates the institution of child labor.

${ }^{36}$ It is possible to argue that in addition to the fact that an educated parent is able to educate her child, the very fact of growing up in a household in which the adults are educated confers knowledge on and therefore increased productivity to a child. This could render the better equilibrium even more dynamic than suggested by this model. For a discussion of the externalities of literacy within a household, see Basu and Foster (1998). 
There is scope for fruitful intervention by government. If an economy is caught in a child labor trap, what is needed is a large effort to educate one generation and this can get the economy rolling towards the virtuous equilibrium without need for further action. Chaudhri (1997) has discussed several versions of "virtuous spirals" and discusses instances of how child labor tends to decline rapidly once a "tipping point" is reached.

As is shown by Parsons and Goldin (1989), the sub-optimality of investment in education is closely-related to the availability of efficient capital markets (see, also, Jacoby and Skoufias, 1997). There is also evidence from the field that the availability of credit on decent terms can rescue many from the perils of child labor, since in developing countries, such as India, a typical reason for a child to drop out of school is not chronic poverty but a temporary mishap for the household, such as the father losing a job or a sibling needing medical support.

The credit question comes up starkly in the model of Baland and Robinson (1998). Theirs is a two-period model of child labor in which inefficiency occurs despite parental altruism, because parents may run out of resources needed to educate the child. The only option then is to borrow against the child's future income, and this is typically not possible. This shows that to solve the problem of child labor one has to go beyond providing perfect capital markets. What is needed is the enforcement of inter-generational contracts, whereby what $i$ borrows for i's child's education is paid back by the child when she grows up and by when i may be dead. But it is not clear that creating institutions for enforcing such contracts is desirable, since it will be open to the moral hazard of 'inverse bequests', whereby a person borrows funds in the name of the child's education and leaves the child with a repayment burden.

Another related feature, that I do not model here but is important, is the fertility decision. 
We have in this paper treated the number of children as exogenously given. In reality, the number of children a family has is partly volitional and the decision may well depend on whether children can find work (Cain, 1977; Rosenzweig and Evenson, 1977; Eswaran, 1996; Bardhan and Udry, 1998). Cain's study of Bangladesh shows that not only do children contribute to household incomes but a boy becomes a net producer by the age of 12 years and after the age of 15 years his cumulative contribution exceeds their cumulative consumption. Plainly, these are features that a proper dynamic model should be able to incorporate. There is need for such a model and the above outline should be viewed as motivation towards it.

\section{Sexual Harassment and Child Labor}

Corporal punishment and sexual exploitation have, at several stages of history, been closely associated with child labor. Commenting on Britain during the industrial revolution, Nardinelli (1982, p. 294) has observed how the use of violence was common against child laborers, though "by the middle of the $19^{\text {th }}$ century it was seldom used for older workers" ${ }^{37}$ In a model on the use of violence with special reference to child labor, Chwe (1990) has tried to explain this asymmetric treatment of adults and children in terms of the lower reservation utility of the latter. Evidence of violence also cropped up repeatedly during the interviews conducted by the British Parliamentary committee investigating child labor in 1832. For instance, a cotton spinner, Thomas Daniel admitted that the child laborers "are always in terror; and ... the reason of their being in a state of terror and fear is, that we are obliged to have our work done, and we are

${ }^{37} \mathrm{Nardinelli}$ argued that the use of violence was a mechanism for raising productivity, a claim that has not gone unchallenged (see Mackinnon and Johnson, 1984, and Nardinelli, 1984). For some contemporary accounts of coerced child labor see Jonathan Silvers, 1996. 
compelled to use the strap...." (British Parliamentary Papers, 1968, p. 325).

In what follows I want to raise a different theoretical question concerning violence and sexual harassment. Consider first the case of adult labor. Is there a case for banning violence against and sexual harassment when these occur as a consequence of voluntary contracting? I will argue that the answer is a conditional yes; and then try to show that the claim may be carried over to the context of child labor to construct a novel argument for banning child labor in certain situations. Though the theoretical claim applies to all kinds of violence, 1 illustrate it here with respect to sexual harassment. This argument goes to the core of the philosophical debate concerning the state's right to ban voluntary transactions between consenting individuals, such as the signing of self-enslavement contracts or trade in human organs or a child's decision to sell his labor. The best of the existing arguments are quite tenuous ${ }^{38}$ and so this is a matter that deserves closer scrutiny.

Economists usually take the line that a voluntary contract between two agents that does not have negative externalities on uninvolved outsiders ought not to be banned. Let me call this the "principle of free contract". If we accept this principle, then it is not clear why sexual harassment in the work place should always be banned. Consider one kind of harassment which is ex ante voluntary. Suppose an entrepreneur advertises for workers, openly saying that he will pay a wage above the market rate but he reserves the right to sexually harass his employees. Therefore, if a worker joins this firm, it must be that she finds that the benefit outweighs the cost. If we accept the principle of free contract, it now seems difficult to justify banning open sexual

${ }^{38}$ For useful discussions of this debate see Ellerman (1992, Chapter 9) and Trebilcock (1993, Chapter, 4). For an outline of the debate on what constitutes sexual harassment, see Hadfield (1995). 
harassment of the kind just described. But I believe there is an argument that can be constructed which respects the principle of free contract, and yet may justify a ban.

Note that under normal assumptions the following is true: If harassment is allowed, then those workers whe are especially strongly averse to harassment will be worse off because the market wage that they will be able to command will be lower than what it would be if no harassment were allowed by law. I call this the "harassment lemma"; and begin by proving it.

Suppose that we have a market with two kinds of workers, with type-1 workers having a stronger aversion to sexual harassment than type- 2 workers. For reasons of algebraic ease let us assume that type 1's distaste for harassment is infinite (so they would rather be unemployed than face harassment), while type 2 's distaste is zero. If the wage rate is $\mathrm{W}$ and there is no harassment, the aggregate supply of labor by type-i workers is $f_{i}(W)$. As usual, $f_{i}^{\prime}(W)>0$.

This is a competitive model; so workers and employers are wage-takers. Let me, for simplicity, assume that there is only one employer and he gets a satisfaction of $\theta(>0)$ from harassing each worker. The production function of the employer is given by $x=x(n)$, where $x^{\prime}>$ $0, \mathrm{x}^{\prime \prime}<0, \mathrm{n}$ is the number of workers and $\mathrm{x}$ the total output.

Let $\mathrm{W}_{\mathrm{H}}$ be the wage for those who sign the with-harassment contract and $\mathrm{W}_{\mathrm{N}}$ for those who sign the no-harassment contract. If the employer hires $\mathrm{n}_{\mathrm{H}}$ workers under the H-contract and $n_{N}$ workers under the $N$-contract, his total profit is $x\left(n_{H}+n_{N}\right)-n_{H} W_{H}-n_{N} W_{N}-\theta n_{H}$. The firstorder conditions from maximizing this can be rearranged and written as follows:

$$
\begin{aligned}
& \mathrm{x}^{\prime}\left(\mathrm{n}_{\mathrm{H}}+\mathrm{n}_{\mathrm{N}}\right)=\mathrm{W}_{\mathrm{N}} \\
& \mathrm{W}_{\mathrm{H}}=\mathrm{W}_{\mathrm{N}}+\theta
\end{aligned}
$$

Clearly, type-1 workers will sign $\mathrm{N}$-contracts and type-2 workers will sign $\mathrm{H}$-contracts. Hence, 
the total supply of workers for $\mathrm{N}$-contracts will be $\mathrm{f}_{1}\left(\mathrm{~W}_{\mathrm{N}}\right)$ and the total supply for $\mathrm{H}$-contracts will be $f_{2}\left(W_{H}\right)$. Therefore, using (9) and (10), we can say that $W_{N}^{*}$ is an equilibrium if

$$
x^{\prime}\left(f_{1}\left(W_{N}^{*}\right)+f_{2}\left(W_{N}^{*}+\theta\right)\right)=W_{N}^{*}
$$

Consider now a legal regime where harassment is never allowed. Hence, there is only one wage in the market, $\mathrm{W}$. The employer maximizes $\mathrm{x}(\mathrm{n})-\mathrm{nW}$. The total supply of labor is given by $f_{1}(W)+f_{2}(W)$. $W^{*}$ is an equilibrium wage if $x^{\prime}\left(f_{1}\left(W^{*}\right)+f_{2}\left(W^{*}\right)\right)=W^{*}$

Since $f_{2}^{\prime}>0$ and $x^{\prime \prime}<0$, it follows that $W_{N}^{*}<W^{*}$. This completes the proof.

What the harassment lemma establishes is this. If we adhere to the principle of free contract, then even though we may have no reason for stopping finite pairs of individuals (an employer and an empoyee) from getting into harassment contracts, there may be good reason for adopting the rule that no harassment contracts should be allowed in the workplace. This is made possible by the fact that, in competition, the aggregate is not simply the sum of all atomistic acts.

Note that the harassment lemma does not provide sufficient reason for banning harassment, but simply shows that allowing contractual harassment cannot be justified on grounds of the principle of free contract, since allowing harassment typically has a negative externality on uninvolved indivduals. Clearly, a negative externality cannot be a sufficient reason for disallowing any action. Otherwise we would have to say that no one should be allowed to work on days when there is a cricket match because otherwise those who like watching cricket will be adversely affected.

To establish a sufficiency criterion, we need go beyond economics and identify human preferences which are 'fundamental' in the sense that no one should have to pay a price for having 
such a preference. This may be a controversial list but very few people will deny that there are such 'fundamental preferences', and also that not all preferences qualify as fundamental. In most societies the preference not to be sexually harassed would be considered fundamental. No one should have to pay a penalty for having such a preference. On the other hand the preference for missing work when a cricket match is on would not be considered fundamental by most of us. You may of course have such a preference but you should be prepared to pay some price for it.

It is the harassment lemma coupled with the recognition that the preference not to be sexually harassed is fundamental that clinches the case for an outright ban on sexual harassment.

It is easy to see that the harassment lemma, as an abstract idea, carries over from the domain of sexual harassment to child labor, by assuming that households have different degrees of aversion to sending their children to work. For concreteness turn to the model of Section $6 \mathrm{~A}$ and assume that there are two types of households, 1 and 2 , where a type-i household is one which would send its children out to work if and only if adult wage drops to below $w_{i}$. Let us assume that $w_{1}=-\infty$ (that is, type 1 households never send their children to work), whereas $w_{2}=\infty$ (that is, type 2 households always send their children to work).

By using a diagrammatic technique similar to the one used in Figure 1 it is immediately obvious that the market wage rises if a ban on child labor is imposed. Conversely, if a ban on child labor is removed, wages must fall; and so type-1 households become worse off. This establishes the counterpart of the harassment lemma.

Therefore, not having a ban on child labor penalizes households that have a stronger preference not to send their children to work. Following the claims of the above subsection, this leads to a case for a ban on child labor if we consider a household's preference not to send its 
children to work to be a fundamental preference. To my mind this is not unambiguously fundamental or non-fundamental. It is plainly more fundamental than a person's preference for missing work during cricket matches and probably less so than a preference for not submitting to harassment. So, while the case is not automatic, this is a possible avenue for justifying legal action against child labor.

\section{International Labor Standards}

A topic closely related to the subject of child labor is that of 'international labor standards' and the use of 'social clauses' as a prerequisite for trade. For many years, overtly or covertly, people have argued the need to enforce some minimal standards of labor, concerning working conditions, duration of work, the level of wages and so on. ${ }^{39}$

Laborers have often had to work in apalling conditions for meagre wages. So a part of the agitation for minimal international labor standards is indeed inspired by a genuine concern for the well-being of workers. But as is only to be expected in such situations, forces of protection and lobbies with their own interest in mind have taken up positions behind this banner. The presence of international organizations make it now possible, what earlier would be infeasible, to bring multi-national pressure to individual nations to comply with some minimal labor standards. In forums, such as the ILO, GATT and now WTO, the subject of labor standards or social clauses has been a live one (Bhagwati, 1995). Some industrialized nations have campaigned for the inclusion of social clauses in the WTO which would either deny nations that do not fulfil minimal

${ }^{39}$ See Charnovitz (1987) and Srinivasan (1996) for discussion of the roots of the laborstandards movement. For a discussion of alternative interpretations of "labor standards" see Sengenberger and Campbell (1994). 
labor standards the membership of WTO or enable other nations to place a trade embargo on any nation that violates the standards.

One major area for setting international labor standards concerns child labor (see Fields, 1995; Bloom and Noor 1996; Maskus and Holman, 1996 and Golub, 1997, Brown, 1998). As an ultimate objective everybody agrees that children should not work, just as adults should not overwork and get underpaid. Given these objectives, what is the right policy response? Here answers have differed widely. One answer is that since one country's acquiescence to lower labor standards gives it trading advantages in labor-intensive goods, there should be multilateral sanctions against such a country; and social clauses should be used to deter such "illegitimate advantages" (see, for instance, Collingsworth, Goold and Harvey, 1994; and Wilkinson, 1994).

At the other end of the spectrum is the argument that countries trade on the basis of their relative advantages and for some countries the advantage lies in their cheap labor. To try to level these out through the use of multilateral threats is to practice protectionism, which is likely to hurt not just workers in the Third World but consumers in the developed nations as well. In particular, several economists have argued that a social clause in the WTO is not the right response to child labor and other problems of labor standards (Bhagwati, 1995; Srinivasan, 1996). Instead, Bhagwati (1995, p. 757) argues for "methods of suasion" and for ILO to be the main international agency to strive towards better standards.

A variety of positions have also been taken between the two described above. Rodrik (1996), for instance, argues that, while one has to be aware that the "upward harmonization"of labor standards can rob poor nations of their comparative advantage in labor-intensive goods, it may be all right to use trade restrictions against nations that violate a widely held moral code in 
the importing country so as to safeguard domestic labor standards. He calls this a "social safeguard clause", and suggests (1) institutional mechanisms for ensuring that these are not misused by one nation against another and (2) a scheme for providing compensation (under certain circumstances) to a developing country that loses out as a consequence of such sanctions. ${ }^{40}$

To check on the impact of imposing international labor standards on developing nations (and to deduce which ones are worthwhile) it is important to have a suitable theoretical model. My interest here is in child labor standards. The theoretical modeling of labor standards is still in its nascency (see Bloom and Noor, 1996; Maskus and Holman, 1996; Srinivasan, 1996). Of these, Maskus and Holman are most directly concerned with child labor standards. Their model is based on introducing the "demand for child labor standards" as an argument in the representative agent's Cobb-Douglas utility function. This makes some of the conclusions, such as the need for child labor standards, too direct a consequence of the assumptions of the model; and it also leaves no margin for the fact the people's attitude to child labor may embody a misunderstanding of the implications of child labor for child welfare.

It seems to me more valuable to analyse policy starting from a standard utility function, instead of one chosen specially for the occasion. In what follows we derive lessons for labor standards from a model which (i) does not introduce 'labor standards' as a direct argument in the utility function and (ii) recognizes the inter-dependence of decisions between nations.

Consider the model of Section 6A. Let us simplify it a little by supposing that all

${ }^{40}$ The idea of compensating developing nations for adopting higher labor standards was originally contained in Ehrenberg (1994). See Krueger (1997) for discussion. 
households are identical and at adult-wage $\overline{\mathrm{W}}$ they draw their children out of the labor force. Let us also assume $\gamma=1$. On the other hand, we complicate the model a little by assuming that while the aggregate demand for labor is given by $\mathrm{AD}$ in Figure 3 and aggregate supply by BCFG (its strange shape is natural and was explained in Section 6A), these demand and supply are evenly distributed over $t$ regions, $R_{1}, \ldots, R_{b}$ of the economy. In other words if there are an aggregate of $\mathrm{N}$ consumers and $\mathrm{n}$ firms each region has $\mathrm{N} / \mathrm{t}$ consumers and $\mathrm{n} / \mathrm{t}$ firms.

In other words, the demand curve $\mathrm{AD}$ is a horizontal summation of the demand of $\mathrm{n}$ identical firms and also the horizontal summation of the demand curves in the $t$ regions..

While we car think of $R_{1}, \ldots, R_{t}$ as different regions of a country, we can also think of these as $t$ countries belonging toa global economy. We could think of these together as belonging to a 'region' of the world. I shall assume that the world price of the good produced by this region is one and, thanks to free trade, nothing that happens in the region can change this price. Labor, on the other hand, is region specific. Workers cannot migrate from one country to another.

What we shall do is to study the impact of child labor laws on welfare with and without capital mobility. In this model I interpret capital mobility entirely in terms of the mobility of firms. In other words we shall consider two alternative scenarios: one where firms can freely move between the $t$ countries (or regions); and another in which the firms are entirely country specific.

Suppose the economy is at the bad equilibrium, $E_{B}$. Wage is $W_{L}$; the total employment is OG. The left-hand panel of Figure 3 depicts what happens in each region. In each region employment is equal to $O^{\prime} G^{\prime}=(O G) / t$. The figure is drawn as if $t=2$.

Consider first the case where firms are region specific. If a ban is imposed on child labor in only one country (the one shown in the left-panel of Figure 3), then, for reasons given in 
Section $5 \mathrm{~A}$, equilibrium will drift from $\mathrm{E}_{\mathrm{B}}^{\prime}$ to $\mathrm{E}_{\mathrm{G}}^{\prime}$ (in the left-panel of Figure 3). In the case illustrated in Figure 3, workers in this region will be better off by the ban.

Figure 3

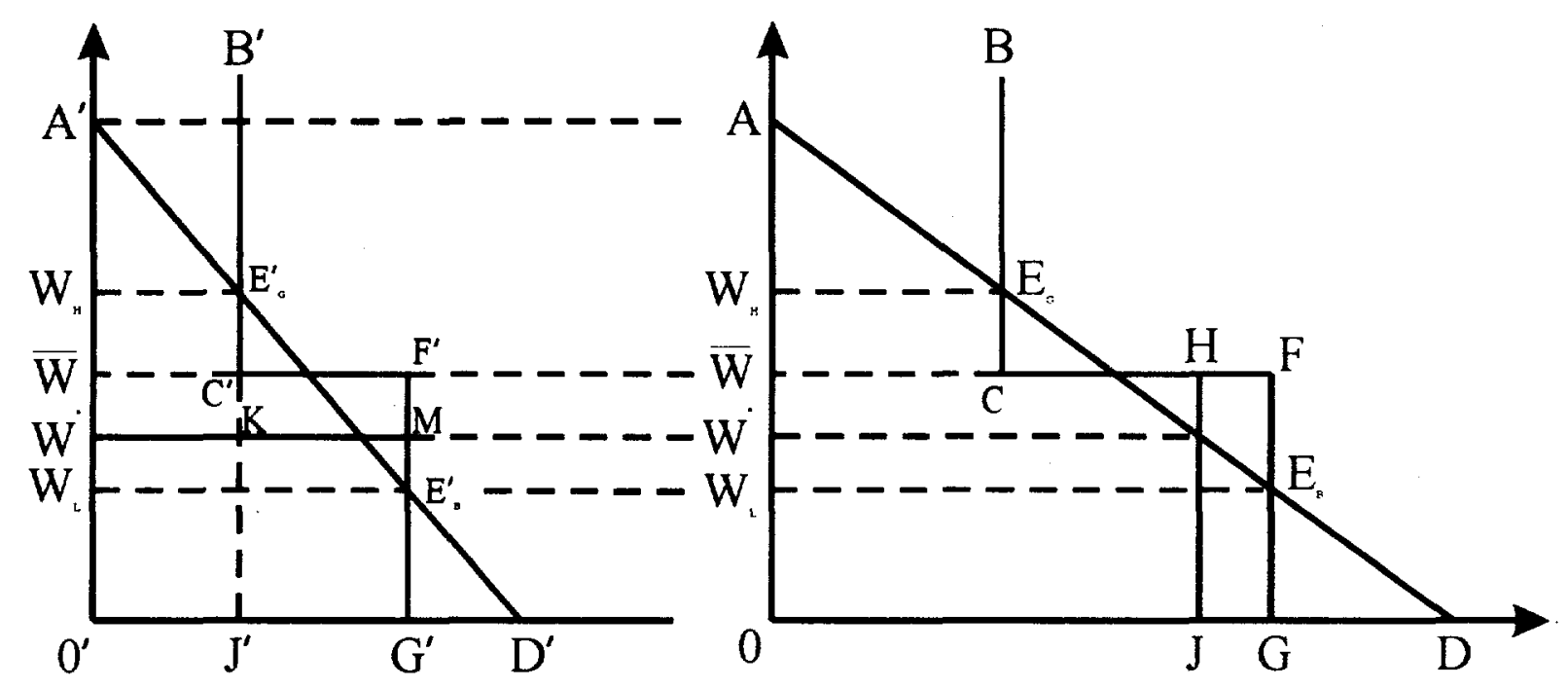

Now suppose firms are fully mobile. Once again consider a ban on child labor imposed only in one country (the one depicted in the left-panel of Figure 3). This will imply that the total labor supply in these $\mathrm{t}$ countries will be $\mathrm{BCHJ}$, where $\mathrm{HF}=\mathrm{CF} / \mathrm{t}$, since child labor from one country is no longer available. ${ }^{41}$ Hence equilibrium wage rises to $W^{*}$.

${ }^{41}$ Note also that JG must be equal to J'G'. 
Let us see what the equilibrium looks like for each individual nation. Clearly, the nation which imposes the ban will be at a point like $\mathrm{K}$, where wage is $\mathrm{W}^{*}$ and total employment is $\mathrm{O}^{\prime} \mathrm{J}^{\prime}$ (i.e. only adults are employed). All other nations are at a point such as $\mathrm{M}$. This is caused by the flight of capital (in this case, firms) from the nation imposing the ban.

In this new equilibrium, the country imposing the ban will have to incur large costs monitoring the ban because it is not in the self-interest of workers and employers to comply with the ban. In addition the workers of this nation are likely to be worse off with the ban. This will be especially true if $t$ is large (which will imply that $\mathrm{W}^{*}$ will be close to $\mathrm{W}_{\mathrm{L}}$ ).

Now suppose that through an international labor standards agreement all nations agree to impose a ban on child labor. There is now no flight of capital since one nation is as good as another. So the aggregate equilibrium shifts to $E_{G}$ and each nation shifts from $E_{B}^{\prime}$ to $E_{G}^{\prime}$. All workers are better off and the ban does not need to be monitored since in this new equilibrium wage is so high (at $\mathrm{W}_{\mathrm{H}}$ ) that parents do not want to send their children to work.

It is true that we get this extreme result by focusing on the case where the aggregate demand curve $\mathrm{AD}$ intersects the aggregate supply curve more than once. Nevertheless, what it illustrates is an important implication of the model of Section $6 \mathrm{~A}$ for international labor standards.

There are contexts where, even though labor standards are undesirable for each nation behaving atomistically, they are worthwhile if the standards are co-ordinated across a large number of nations and indeed once this is achieved it may be in the self-interest of everybody to live by the standards.

One must acld some notes of caution to the above proposition. First, the proposition must not be taken to detract from the claim that labor standards are often a front for protectionism. 
The proposition claims that it is possible for co-ordinated effort to benefit all. It does not say that this will always be the case. What the proposition highlights is the fact that coordinated effort is better than individual effort. Second, it is conceivable that once we allow for the heterogeneity of nations, the case will be (when there is a case at all) for labor standards which vary across nations. Third, if we worked with a demand curve which was sufficiently low so that it intersects the aggregate supply curve of labor once and on the segment FG, we would find that even a coordinated labor standards imposed on all nations will need monitoring (compliance being not in the self-interest of all individuals), though it will continue to be the case that it is better to have a coordinated effort rather than one imposed idiosyncratically on some nations.

\section{Conclusion}

The literature on child labor is an illustration of abundance and anarchy. Theoretical writings on the subject are relatively few though one finds theoretical insights in many unexpected papers and books which may be otherwise purely empirical or descriptive. The empirical writings on child labor are numerous but they are usually not founded on any theory. By bringing together the main theoretical ideas, this survey hopes to encourage not just further theoretical research but empirical work which is analytically better founded.

Also evident from this survey is the fact that there is no unique prescription. Should child labor be banned outright? Should the WTO be given the responsibility of enforcing restrictions on child labor through the use of trade sanctions? Should there be a legal minimum wage for adults so as to make it unnecessary for parents to send their children to work? The answer depends on the context. 
It was argued in this paper that there is much that can and ought to be done, but the precise policy to be followed depends on the economic milieu for which the prescription is being sought. The main policy divide is between legal interventions and what may be called collaborative interventions, that is, public action which alters the economic environment such that parents of their own accord prefer to withdraw the children from the labor force. The availability of good schools, the provision of free meals, effort to bolster adult wages, are examples of collaborative interventions. We have discussed examples and given arguments to show that such interventions are, in general, a desirable way of curbing child labor. However, many of these actions may not be feasible. There may not be money enough in the government's coffers to run better schools or to improve the infrastructure which would result in higher adult wages.

In such circumstances, should government resort to legal action to restrict child labor? There seems to be some agreement, that some minimal restrictions, such as children being prevented from working in hazardous occupations or under bonded labor conditions, are worth enforcing legally. It is true that one can always think of some circumstance where even such a minimal law will work to the detriment of the child. But, by and large, children being made to work in hazardous conditions is either an act of child abuse or ignorance on the part of the parents and the child and so, in general, it is better to declare such action as illegal.

But what about a more general ban on child labor per se? The evidence and the theory that we studied in this paper suggest that there is no unconditional answer to this. There are circumstances where, even if such a total ban were feasible and costless to implement, it ought not to be implemented. To understand this one must realize that there are worse things that can happen to children than having to work. In very poor regions, the alternative to work may be to 
suffer acute hunger or starvation. Indeed, when child labor occurs as a mass phenomenon, it is likely that the alternative to work is very harsh; because even poor parents do not in general like to send their children to work if they can help it.

Curiously enough, despite this, there are circumstances where a total ban may be desirable from the point of view of the well-being of the children. This is because, whereas a single parent withdrawing the child from work cannot influence equilibrium wages, a large scale withdrawal of child labor can cause adult wages to rise so much that the working class household is better off. It was argued in this paper that this is unlikely to be true for very poor economies but may be valid for relatively better off countries. Even so, one would need to do detailed empirical work to decide whether such a total ban is worthwhile. The interesting insight that theory gives us here is to tell us that it may be so and to give some hints about the type of economy where this is likely.

Another thing that we know is that, if a ban is deemed desirable, a good way to implement it is by making schooling compulsory. This is because a child's presence in school is easier to monitor than a child's abstention from work. It is true that schooling is compatible with a certain amount of work, since children can work before and after school; but it is a good way to prevent full-time work and of course is desirable in itself. It has, in fact, been argued by some that, in very poor countries, we should make it possible for children to combine school with work, instead of thinking of these as mutually exclusive activities.

The case for a ban on child labor in the export goods sector alone, which would be a natural concomitant of effort in industrialized nations to boycott the import of goods made with child labor, is weaker, since this could result in children being diverted to less desirable or more hazardous work. In general, it is better to take economy-wide measures against child labor and, if 
there is to be a sector-specific ban, this should be based on the working conditions of that sector, rather than the destination of the goods.

This reservation carries over to certain kinds of international action, such as the imposition of minimal labor standards as a prerequisite for trade, since this results in the maintenance of standards only in the exports sector. In addition, international labor standards can cause trade distortions by failing to recognize the comparative advantages of different nations. The paper used some of the models of child labor to investigate the impact of international standards. It was found that one beneficial affect of such standards could be the help that they can provide to developing nations to make a coordinated improvement in their working conditions, without causing a flight of capital. The idea of international labor standards as an instrument of collusion among developing countries suggests news ways to think about this problem. The discussion here was brief and preliminary and simply points to directions for future research. 


\section{References}

Addison, Tony, Bhalotra, Sonia, Coulter, Fiona and Heady, Christopher (1997), 'Child Labor in Pakistan and Ghana: A Comparative Study', mimeo: University of Warwick.

Agarwal, Bina (1997), ' Bargaining" and Gender Relations: Within and Beyond the Household', Feminist Economics, vol. 3(1), 1-51.

Anderson, Michael (1971), Family Structure in Nineteenth (entury Lancashire, Cambridge University Press, Cambridge.

Angrist, Joshua and Krueger, Alan (1991), 'Does Compulsory School Attendance Affect Schooling and Attendance?', Quarterly Journal of Economics, vol. 106, 979-1014.

Ashagrie, Kebebew (1993), 'Statistics on Child Labor', Bulletin of Labor Statistics, Issue No. 3, International Labor Organization, Geneva.

Ashagrie, Kebebew (1998), 'Statistics on Child Labor and Hazardous Child Labor in Brief', mimeo, Bureau of Labor Statistics, ILO, Geneva.

Bachman, Sarah L. (1995), 'Children at Work', Commentary, San Jose Mercury News, July 16.

Baland, Jean-Marie and Robinson, James (1998), 'A Model of Child Labor', mimeo: Namur.

Banerjee, Abhijit and Newman, Andrew (1993), 'Occupational Choice and the Process of Development', Journal of Political Economy, vol. 101, 274-98.

Bardhan, Pranab and Udry, Christopher (1998), Development Microeconomics, manuscript, Yale University.

Basu, Alaka Malwade (1993), 'Family Size and Child Welfare in an Urban Slum: Some Disadvantages of Being Poor but Modern', in Cynthia B. Lloyd (ed.), Fertility, Family Size and Structure, Population Council, New York.

Basu, Kaushik (1994), 'The Poor need Child Labor', New York Times, Nov. 29.

Basu, Kaushik (1998), 'Social Norms and the Law', in The New Palgrave Dictionary of Economics and the Law, Macmillan, London.

Basu, Kaushik and Foster, James (1998), 'On Measuring Literacy', Economic Journal, forthcoming.

Basu, Kaushik, and Van, Pham Hoang (1998), 'The Economics of Child Labor', American 
Economic Review, vol. 88, 412-27

Becker, Gary S. (1964), Human Capital, Columbia University Press, New York.

Besley, Tim and Coate, Steve (1992), 'Understanding Welfare Stigma: Taxpayer Resentment and Statistical Discrimination', Journal of Public Economics, vol. 48, 165-83.

Bhagwati, Jagdish (1995), 'Trade Liberalization and 'Fair Trade' Demands: Addressing the Environment and Labor Standards Issues', World Economy, vol. 18.

Bhatty, Kiran et al (1997), 'Class Struggle', India Today, vol. 22, October 13, 69-73.

Bloom, David and Noor, Waseem (1996), 'Labor Standards and the Emerging World Economy', nimeo: Harvard University.

Bolin-Hort, P. (1989), Work, Family, and the State: (hild Labor and the Organization of Production in the British Cotton Industry, 1780-1920, Lund University Press, Lund.

Bonnet, Michel (1993), 'Child Labor in Africa', International Labor Review, vol. 132(3), 371-89.

Bourguignon, Francois and Chiappori, Pierre-Andre (1994), 'The Collective Approach to Household Behavior', in Richard Blundell, Ian Preston and Ian Walker (eds), The Measurement of Household Welfare, Cambridge University Press, Cambridge, U.K.

British Parliamentary Papers (1968), Report from the Select Committee [1831-32] on the "Bill to Regulate the Labor of Children in the Mills and Factories of the United Kingdom" with Minutes of Evidence (Industrial Revolution: Children's Employment, vol. 2), Irish University Press, Shannon, Ireland.

Brown, Drusilla (1998), 'A Transactions Cost Politics Analysis of International Child Labor Standards', mime: Tufts University.

Brown, Martin, Christiansen, Jens and Philips, Peter (1992), 'The Decline of Child Labor in the US Fruit and Vegetable Canning Industry: Law or Economics', Business History Review, vol. 66(4), 723-70.

Browning, Martin, Bourguignon, Francois, Chiappori, Pierre-André, and Lechene, Valérie (1994), 'Income and Outcomes: A Structural Model of Intrahousehold Allocation', Journal of Political Economy, vol. 102, no. 6.

Burra, Neera (1995), Born to Work: Child Labor in India, Oxford University Press, Delhi.

Cain, Mead T. (1977), 'The Economic Activities of Children in a Village in Bangladesh', 
Population and Development Review, vol. 3(3), 201-27.

Cartwright, Kimberly and Patrinos, Harry A. (1998), 'Child Labor in Urban Bolivia', in Christiaan Grootaert and Harry A. Patrinos (eds.), The Policy Analysis of Child Labor: A

Comparative Study, manuscript: World bank, Washington.

Chandrasekhar, C.P. (1997), 'The Economic Consequences of the Abolition of Child Labor', Journal of Peasant Studies, vol. 24(3), 137-79.

Charnovitz, S. (1987), 'The Influence of International Labor Standards on the World Trading Regime: A Historical Review', International Labor Review, no. 126.

Chaudhri, D.P. (1997), 'A Policy Perspective on Child Labor in India with Pervasive Gender and Lrban Bias in School Education', Indian Journal of Labor Economics, vol. 40(4), 789808 .

Chwe, Michael Suk-Young (1990), 'Why Were Workers Whipped? Pain in a Principal-Agent Model', Economic Journal, vol. 100, 1109-21.

Collingsworth, Terry, Goold, William J. and Harvey, Pharis J. (1994), 'Time for a New Global Deal, Foreign Affairs.

Cunningham, Hugh (1990), 'The Employment and Unemployment of Children in England c. 16801851', Past and Present, No. 126, 115-50.

Cunningham, Hugh (1996), 'Combating Child Labor: The British Experience', in Cunningham and Viazzo (1996).

Cunningham, Hugh and Viazzo, Pier Paolo (eds.) (1996), Child Labor in Historical Perspective, 1800-1985: Case Studies from Europe, Japan and Colombia, UNICEF, Florence.

Cunningham, Hugh and Viazzo, Pier Paolo (1996a), 'Some Issues in the Historical Study of Child Labor', in Cunningham and Viazzo (1996).

Dasgupta, Partha (1993), An Inquiry into Well-Being and Destitution, Oxford University Press, Oxford.

De Herdt, Rene (1996), 'Child Labor in Belgium, 1800-1914', in Cunningham and Viazzo (1996).

Dixit, Avinash (1998), 'Discussion of "A Transactions Cost Politics Analysis of International Child Labor Standards"', mimeo: Princeton University.

Dreze, Jean and Gazdar, Harris (1996), 'Uttar Pradesh: The Burden of Inertia', in Dreze, Jean and 
Sen, Amartya, eds., Indian Development: Selected Regional Perspectives, Oxford University Press, Oxford.

Ehrenberg, Ronald G. (1994), Labor Markets and Integratirg National Economies, Brookings Institution, Washington, D.C.

Ellerman, David (1992), Property and Contract in Economics, Blackwell, Cambridge, MA.

Eswaran, Mukesh (1996), 'Fertility, Literacy and the Institution of Child Labor', mimeo: University of British Columbia, Vancouver.

Fields, Gary S. (1995), 'Labor Standards and International Trade', mimeo: OECD, Paris.

Folbre, I'ancy (1986), 'Hearts and Spades: Paradigms of Household Economics', World Development, vol. 14(2), 245-55.

Francois, Patrick (1998), 'Gender Discrimination without Gender Difference: Theory and Policy Responses', Journal of Public Economics, forthcoming.

Galbi, D.A. (1997), 'Child Labor and the Division of Labor in the Early English Cotton Mills', Journal of Population Economics, vol. 10, no. 4.

Galor, Oded and Zeira, J. (1993), 'Income Distribution and Macroeconomics', Review of Economic Studies, vol. 60, 35-52

Genicot, Garance (1998), 'An Efficiency Wage Theory of Child Labor: Exploring the Implications of Some Ideas of Leibenstein and Marx', Department of Economics, Working Paper \# 463, Cornell University.

Glomm, Gerhard (1997), 'Parental Choice of Human Capital Investment', Journal of Development Economics, vol. 53, 99-114.

Goldin, Claudia D. (1979), 'Household and Market Production of Families in a Late Nineteenth Century American Town', Explorations in Economic History, vol. 16, 111-31.

Golub, Stephen S. (1997), 'Are International Labor Standards needed to Prevent Social Dumping?', Finance and Development, December.

Granovetter, Mark (1978), 'Threshold Models of Collective Behavior', American Journal of Sociology, vol. 83, 1420-43.

Grootaert, Christiaan (1998), 'Child Labor in Cote d'Ivoire: Incidence and Determinants', in Grootaert, Christiaan and Patrinos, Harry, eds., The Policy Analysis of Child Labor: A Comparative Study, manuscript, World Bank, Washington. 
Grootaert, Christiaan, and Kanbur, Ravi (1995), 'Child Labor: An Economic Perspective', International Labor Review, vol. 134, no. 2.

Gupta, Manash R. (1997), 'Unemployment of Adult Labor and the Supply of Child Labor: A Theoretical Analysis', mimeo: Jadavpur University, Calcutta.

Gupta, Manash R. (1998), 'Wage Determination of a Child Worker: A Theoretical Analysis', Review of Development Economics, forthcoming.

Hadfield, Gillian K. (1995), 'Rational Women: A Test for Sex-Based Harassment', California Low Review, vol. 83, 1151-89.

Harkin, . en. Tom (1994), 'Now Act to Ban the Products of Child Labor', Letter to the editor, New York Times, December 5.

Horan, Patrick M. and Hargis, Peggy G. (1991), 'Children's Work and Schooling in the Late Nineteenth Century Family Economy', American Sociological Review, vol. 56(5), 583-96.

Horrell, Sara, and Humphries, Jane (1995), ' "The Exploitation of Little Children": Child Labor and the Family Economy in the Industrial Revolution', Explorations in Economic History, vol. 32 , no. 4 .

Horrell, Sara, and Humphries, Jane (1995a), 'Women's Labor Force Participation and the Transition to the Male-breadwinner Family, 1790-1865', Economic History Review, vol. 48.

Hutchins, B.L. and Harrison, A. (1903), A History of Factory Legislation, P.S. King and Son, London. [References to the 1966 edition by Cass, London.]

ILO (1995), Child Labor in Nepal: An Overview and a Proposed Plan of Action, International Labor Organization, Geneva.

ILO (1996), Child Labor: Targeting the Intolerable, International Labor Organization, Geneva.

ILO (1996a), Economically Active Populations: Estimates and Projections, 1950-2010, International Labor Organization, Geneva.

Jacoby, Hanan G. and Skoufias, Emmanuel (1997), 'Risk, Financial Markets, and Human Capital in a Developing Country', Review of Economic Studies, vol. 64, 311-35.

Jayaraj, D. and Subramanian, S. (1997), 'Child Labor in Tamilradu: A Preliminary Account of its Nature, Extent and Distribution', Working Paper No. 151, Madras Institute of Development Studies, Chennai. 
Jensen, P. and Nielsen, H.S. (1997), 'Child Labor or School Attendance? - Evidence from Zambia', Journal of Population Economics, vol. 10, no. 4.

Kelway, A. J. (1906), 'Child labor in the Southern Cotton Mills', Annals of the American Academy of Political and Social Science, vol. 28, 1-11.

Knutsson, Karl Eric (1997), Children: Noble Causes or Worthy Citizens?, Ashgate Publishing, Aldershot, U.K.

Kothari, Smitu (1983), 'There's Blood on those Matchsticks: Child Labor in Sivakasi', Economic and Political Weekly, vol. 28, no. 27.

Krueger, Alan (1997), 'International Labor Standards and Trade', in Proceedings of the Anmual World Bank Conference on Development Economics, 1996, World Bank, Washington.

Kruse, Douglas and Mahoney, Douglas (1998), 'Illegal Child Labor in the United States: Prevalence and Characteristics', NBER Working Paper No. 6479.

Kulkarni, Manu (1983), 'Matchmaking Children of Sivakasi', Economic and Political Weekly, October 22 .

Labenne, Sophie (1995), 'Determinants of Child Labor in India', Universite de Namur, Belgium.

Levison, Deborah et al (1998), 'Is Child Labor Really Necessary in India's Carpet Industry?', in Anker, Richard et al (eds.), Economics of Child Labor in Selected Industries of India, Hindustan Publishers, New Delhi, forthcoming.

Levy, Victor (1985), 'Cropping Pattern, Mechanization, Child Labor, and Fertility Behavior in a Farming Economy: Rural Egypt', Economic Development and Cultural Change, vol. 33(4), 777-91

Lindbeck, Assar, Nyberg, Stan and Weibull, Jorgen (1998), 'Social Norms and Economic Incentives in the Welfare State', Quarterly Journal of Economics, forthcoming.

Ljungqvist, Lars (1993), 'Economic Underdevelopment: The Case of a Missing Market for Human Capital', Journal of Development Economics, vol. 40, 219-39.

Lyons, John (1989), 'Family Response to Economic Decline: Handloom Weavers in Early Nineteenth-Century Lancashire', Research in Economic History, vol. 12, 45-91.

Mackinnon, Mary and Paul Johnson (1984), 'The Case Against Productive Whipping', Explorations in Economic History, vol. 21, 218-23. 
Maharatna, Arup (1997), 'Children's Work Activities, Surplus Labor and Fertility: Case Study of Six Villages in Birbhum', Economic and Political Weekly, vol. 32, February 15, pp. 363-9.

Manser, Marilyn and Murray Brown (1980), 'Marriage and Household Decision-Making: A Bargaining Analysis', International Economic Review, vol. 21, 31-44.

Margo, R.A. and Finegan, T.A. (1996), 'Compulsory Schooling Legislation and School Attendance in the Turn of the Century America', Economics Letters, vol. 53, 103-10.

Marshall, Alfred (1920), Principles of Economics, $8^{\text {th }}$ edition, Macmillan, London. [Original publication 1890].

Marx, Karl (1875), Critique of the Gotha Programme.[References to the 1938 English translation in Marx, Karl and Engels, Frederick, Selected Works, Vol. II, International Publishers, New York.]

Marx, Karl (1967), Capital: A Critique of Political Economy. [References to the 1954 edition, Progress Publishers, Moscow.]

Maskus, Keith E., and Holman, Jill A. (1996), 'The Economics of Child Labor Standards', mimeo: Department of Economics, University of Colorado at Boulder.

McElroy, Marjorie and Mary Jean Horney (1981), 'Nash-Bargained Household Decisions: Towards a Generalization of the Theory of Demand', International Economic Review, vol. $22,333-49$.

Mill, John Stuart (1970), Principles of Political Economy, Penguin, Harmondsworth, U.K. [original publication 1848].

Moehling, Carolyn M. (1995), 'The Intrahousehold Allocation of Resources and the Participation of Children in Household Decision-Making: Evidence from Early Twentieth Century America', mimeo: Northwestern University.

Moehling, Carolyn (1998), 'State Child Labor Laws and the Decline of Child Labor', mimeo: Ohio State University.

Myers, William (1988), 'Alternative Services for Street Children: The Brazilian Approach', in Bequele and Boyden (1988).

Nardinelli, Clark (1982), 'Corporal Punishment and Children's Wages in Nineteenth-Century Britain', Explorations in Economic History, vol. 19, 283-95.

Nardinelli, Clark (1984), 'The Productivity of Corporal Punishment: A Reply to Mackinnon and 
Johnson', Explorations in Economic History, vol. 21, 224-8.

Nardinelli, Clark (1990), Child Labor and the Industrial Revolution, Indiana University Press, Bloomington.

Parsons, Donald O. and Claudia Goldin (1989), 'Parental Altruism and Self-Interest: Child Labor among late Nineteenth-Century American Families', Economic Inquiry, vol. 27, 637-60.

Patrinos, Harry A. and Psacharopoulos, George (1997), 'Family Size, Schooling and Child Labor in Peru', Journal of Population Economics, vol. 10, no. 4.

Pigou, Arthur C. (1920), The Economics of Welfare. [References to the 1962 edition, Macmillan, London ].

Psacharopoulos, G. (1997), 'Child Labor Versus Educational Attainment - Some Evidence from Latin America,' Journal of Population Economics, vol. 10, no. 4.

Ray, Ranjan (1998), 'Analysis of Child Labor in Peru and Pakistan: A Comparative Study', mimeo: Hobart, Australia.

Riley, Nancy E. (1997), 'Gender, Power, and Population Change,' Population Bulletin, vol.52, $2-46$.

Rodgers, Gerry and Standing, Guy, eds. (1981), Child Work, Poverty, and Underdevelopment, International Labor Organization, Geneva.

Rodrik, Dani (1996), 'Labor Standards in International Trade: Do They Matter and What do we do about Them?' Policy Essay No.20, Overseas Development Council, Washington, DC.

Rodrik, Dani (1997), Has Globalization Gone too Far? Institute for International Economics, Washington, D.C.

Rosenzweig, Mark R. and Robert Evenson (1977), 'Fertility, Schooling and the Economic Contribution of Children in Rural India: An Econometric Analysis', Econometrica, vol. 45, 1065-79.

Saito, Osamu (1996), 'Children's Work, Industrialization and the Family Economy in Japan, 18721926', in Cunningham and Viazzo (1996).

Scholliers, Peter (1995), 'Grown-ups, Boys and Girls in the Ghent Cotton Industry: The Voortman Mills, 1835-1914', Social History, vol. 20.

Sen, Amartya K. (1990), 'Gender and Cooperative Conflict', in Tinker, I. (ed.), Persistent 
Inequalities, Oxford University Press, New York.

Sengenberger, Werner and Campbell, Duncan (eds.), (1994), International Labor Standards and Economic Interdependence, International Institute for Labor Studies, Geneva.

Silvers, Jonathan (1996), 'Child Labor in Pakistan', The Atlantic Monthly, February, 79-92.

Srinivasan, T.N. (1996), 'International Trade and Labor Standards from an Economic Perspective', in P. van Dyck and G. Faber (eds.), (hallenges to the New World Trade Organization, Kluwer Publishers.

Strauss, John and Thomas, Duncan (1995), 'Human Resources: Empirical Modeling of Household and Family Decisions', in Behrman, Jere and Srinivasan, T.N., eds., Handbook of Development Economics, Vol. IIIA, Elsevier, Amsterdam.

Swaminathan, Madhura (1997), 'Do Child Workers acquire Specialized Skills? A Case Study of Teenage Worke s in Bhavnagar', Indian Journal of Labor Economics, vol. 40(4), 829-39.

Swinnerton, Kenneth and Rogers, Carol Ann (1998), 'The Economics of Child Labor: Comment', mimeo: US Department of Labor, Bureau of International Labor Affairs, Washington.

Thomas, Duncan (1990), 'Intra-Household Resource Allocation: An Inferential Approach', Journal of Human Resources, vol. 25(4), pp. 635-64.

Trebilcock, Michael (1993), The Limits of Freedom of Contract, Harvard University Press, Cambridge, MA.

Udry, Christopher (1996), 'Gender, Agricultural Production and the Theory of the Household', Journal of Political Economy, vol. 104(5), pp. 1010-46.

UNICEF (1994), Children at Work, UNICEF East Asia and Pacific Regional Office, Bangkok.

United States Department of Labor (1993), Foreign Labor Trends: International Child Labor Problems, Bureau of International Labor Affairs, Washington, D.C.

Vincent, David (1981), Bread, Knowledge and Freedom: A Study of Nineteenth-Century Working Class Autobiography, Europa Publications, London.

Weiner, Myron (1996), 'Child Labor in India: Putting Compulsory Primary Education on the Political Agenda', Economic and Political Weekly, vol. 31, pp. 45-6, November 9-16.

Weiner, Myron (1991), The Child and the State in India: Child Labor and Education Policy in Comparative Perspective, Princeton University Press, Princeton. 
Wilkinson, Frank (1994), 'Equality, Efficiency and Economic Progress: the Case for Universally Applied Equitable Standards for Wages and Conditions of Work' in Werner Sengenberger and Duncan Campbell (1998). 
Titse

WPS2007 Regional integration Arrangements: Static Economic theory, Quantitative Findings, and Policy Guidelines

WPS2008 Volatility and Contagion in a Financially Integrated World: Lessons from East Asia's Recent Experience
Author

Pedro Alba

Amar Bhattacharya

Stijn Claessens

WPS2009 Poverty and the Economic Transition: Peter Lanjouw How Do Changes in Economies of Scale Affect Poverty Rates for Different Housenolds?

WPS2010 The Real Impact of Financial Shocks: Ilker Domaç Evidence from the Republic of Korea Giovanni Ferri

WPS2011 Measuring Poverty Using Qualitative Perceptions of Welfare

WPS2012 Export Quotas and Policy Constraints Sanjay Kathuria in the Indian Textile and Garment Anjali Bhardwaj Industries

WPS2013 A New Databasse on Investment and Capital for Agriculture and Manufacturing

WPS2014 Land Institutions and Land Markets

WPS2015 The Mechanics of Progress in Education: Evidence from CrossCountry Data

WPS2016 Financial Services for the Urban Poor: South Africa's E Plan

WPS2017 Corporate Growth, Financing, and Risks in the Decade before East Asia's Financial Crisis

WPS2018 Prerequisites for a DevelopmentOriented State in the Democratic Republic of the Congo
Dean A. DeRosa

Swati Ghosh

Leonardo Hernandez

Menno Pradhan Martin Ravallion

\section{Date}

Contact

for paper

November 1998

L. Tabada 36896

November 1998

D. Fischer 38656

November 1998

P. Sader 33902

November 1998

M. Greaves 81876

November 1998

P. Sader 33902

November 1998

L. Tabada 36896

November 1998

P. Kokila 33716

Donald Larson

Rita Butzer

Yair Mundlak

Klaus Deininger

Gershon Feder

Alain Mingat Jee-Peng Tan

Jo Ann Paulson James McAndrews

Stijn Claessens

Simeon Djankov Larry Lang

Mondonga M. Mokoli Hans P. Binswanger
November 1998 30898

November 1998

A. Thornton 80409

M. Fernandez 33766

A. Poghosyan

November 1998

R. Vo 33722

November 1998

H. Binswanger 31871 
Title

WPS2019 The Effects on Developing Countries of the Kyoto Protocol and Carbon Dioxide Emissions Trading

WPS2020 Trade Liberalization, Fiscal Adjustment, and Exchange Rate Policy in India

WPS2021 Balance, Accountability, and Responsiveness: Lessons about Decentralization

WPS2022 The Implications of Foreign Aid Fungibility for Development Assistance

WPS2023 Capital Inflow Reversals, Banking Stability, and Prudential Regulation in Central and Eastern Europe

WPS2024 Re-Engineering Insurance Supervision

WPS2025 Dynamic Capital Mobility, Capital Market Risk, and Exchange Rate Misalignment: Evidence from Seven Asian Countries

WPS2026 Circuit Theory of Finance and the Role of Incentives in Financial Sector Reform
Author

A. Denny Ellerman Henry D. Jacoby Annelene Decaux

Delfin S. Go

Pradeep Mitra

Anwar Shah

Shantayanan Devarajan Vinaya Swaroop

Samuel Talley

Marcelo M. Giugale

Rossana Polastri

Lawrie Savage

Hong $G$. Min

Biagio Bossone
Date

December 1998

December 1998

December 1998

Contact

for paper

T. Tourougui 87431

C. Bernardo 31148

A. Shah 37687

December 1998

C. Bernardo 31148

December 1998

M. Geller 85155

December 1998

H. Arbi 34663

December 1998

K. Labrie 31001

December 1998

B. Bossone 33021 